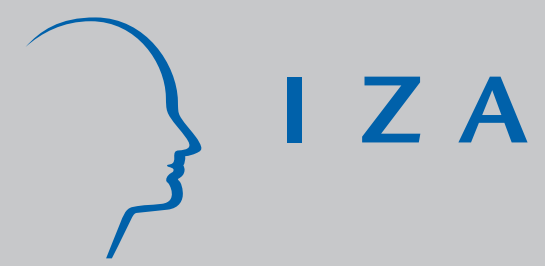

IZA DP No. 7623

The Structure of the Permanent Job Wage Premium: Evidence from Europe

Lawrence M. Kahn

September 2013

Forschungsinstitut zur Zukunft der Arbeit Institute for the Study of Labor 


\title{
The Structure of the Permanent Job Wage Premium: Evidence from Europe
}

\author{
Lawrence M. Kahn \\ Cornell University, \\ CESifo, IZA and NCER
}

\section{Discussion Paper No. 7623 \\ September 2013}

\author{
IZA \\ P.O. Box 7240 \\ 53072 Bonn \\ Germany \\ Phone: +49-228-3894-0 \\ Fax: +49-228-3894-180 \\ E-mail: iza@iza.org
}

Any opinions expressed here are those of the author(s) and not those of IZA. Research published in this series may include views on policy, but the institute itself takes no institutional policy positions. The IZA research network is committed to the IZA Guiding Principles of Research Integrity.

The Institute for the Study of Labor (IZA) in Bonn is a local and virtual international research center and a place of communication between science, politics and business. IZA is an independent nonprofit organization supported by Deutsche Post Foundation. The center is associated with the University of Bonn and offers a stimulating research environment through its international network, workshops and conferences, data service, project support, research visits and doctoral program. IZA engages in (i) original and internationally competitive research in all fields of labor economics, (ii) development of policy concepts, and (iii) dissemination of research results and concepts to the interested public.

IZA Discussion Papers often represent preliminary work and are circulated to encourage discussion. Citation of such a paper should account for its provisional character. A revised version may be available directly from the author. 


\title{
ABSTRACT
}

\section{The Structure of the Permanent Job Wage Premium: Evidence from Europe}

\begin{abstract}
Using longitudinal data on individuals from the European Community Household Panel (ECHP) for thirteen countries during 1995-2001, I investigate the wage premium for permanent jobs relative to temporary jobs. The countries are Austria, Belgium, Denmark, Finland, France, Germany, Greece, Ireland, Italy, the Netherlands, Portugal, Spain, and the United Kingdom. I find that among men the wage premium for a permanent vs. temporary job is lower for older workers and native born workers; for women, the permanent job wage premium is lower for older workers and those with longer job tenure. Moreover, there is some evidence that among immigrant men, the permanent job premium is especially high for those who migrated from outside the European Union. These findings all suggest that the gain to promotion into permanent jobs is indeed higher for those with less experience in the domestic labor market. In contrast to the effects for the young and immigrants, the permanent job pay premium is slightly smaller on average for women than for men, even though on average women have less experience in the labor market than men do. It is possible that women even in permanent jobs are in segregated labor markets. But as noted, among women, the permanent job wage premium is higher for the young and those with less current tenure, suggesting that even in the female labor market, employers pay attention to experience differences.
\end{abstract}

JEL Classification: J31, J42

Keywords: $\quad$ wage structure, segmented labor markets, temporary jobs

Corresponding author:

Lawrence M. Kahn

Cornell University

258 Ives Hall

Ithaca, New York 14583

USA

E-mail: Imk12@cornell.edu

\footnotetext{
* Preliminary draft. Comments welcome. The author is grateful to Alison Davies and Rhys Powell for their aid in acquiring the European Labour Force Survey regional unemployment rate data. This paper uses European Community Household Panel data (Users Database, waves 1-8, version of December 2003), supplied courtesy of the European Commission, Eurostat. Data are obtainable by application to Eurostat, which has no responsibility for the results and conclusions of this paper.
} 


\section{Introduction}

A considerable volume of economic research has been devoted over the last two decades to explaining and suggesting remedies for the stubbornly high unemployment rates in a number of European countries. Among the suggested policy remedies for reducing joblessness is the relaxation of systems of employment protection by allowing firms greater freedom to create temporary jobs. These reforms presumably reflect a desire to maintain protections for workers in permanent jobs while giving firms an incentive to create new, temporary jobs, which may ultimately become permanent. And even if they don't become permanent, temporary jobs may in some cases provide employment and work experience for individuals who would otherwise have been unemployed. On the other hand, policies increasing employers' freedom to create temporary jobs may instead encourage firms to substitute temporary for permanent jobs (as found by Kahn 2010), and, if so, the overall exit rate from jobs may increase. The resulting higher turnover may even lead to higher equilibrium unemployment than before (Blanchard and Landier 2002; Cahuc and Postel-Vinay 2002). Moreover, temporary jobs are known to pay less, offer less training, and be less satisfying than regular jobs (Booth, Francesconi and Frank 2002; Boeri 2011; Kahn 2007 and 2012; Stancanelli 2002). And previous research has found that the young, immigrants and women are disproportionately concentrated in temporary jobs, which are sometimes seen as part of a process leading to labor market dualism, due to the lower pay in temporary jobs and barriers to entering permanent jobs (Kahn 2007).

In this paper, I use European Community Household Data to investigate the premium workers command in permanent jobs relative to temporary jobs across thirteen European countries: Austria, Belgium, Denmark, Finland, France, Germany, Greece, Ireland, Italy, the Netherlands, Portugal, Spain, and the United Kingdom. A basic framework to understand this issue comes from Blanchard and Landier's (2002) research in which it is assumed that firms start workers in temporary jobs. Then as the expiration of the job approaches, the firm must decide whether to promote the worker into a permanent job or whether to start over with a new match in 
a temporary job. In the presence of higher firing costs for permanent jobs relative to temporary jobs, firms will be reluctant to make such promotions unless the economic circumstances of the firm warrant it. Once promoted, workers are able to appropriate some of the firing costs, since these raise the value of continuing the employment match once the worker is promoted. Thus, an important determinant of the wage premium in a permanent job is the value of the match relative to breaking it up and starting over with a temporary employee.

I hypothesize that before being promoted into a permanent job, inexperienced workers must receive training in the temporary job to which they have been hired. In equilibrium, their starting wages in the temporary job will be below the level of starting wages for experienced, trained workers starting a temporary job. After they have become trained, the firm may receive a productivity shock which will determine whether it will promote the workers. By this time, experienced and inexperienced workers will each be trained and thus will be treated similarly by the firm. Because of the wage discount at the beginning of the temporary job for less inexperienced workers, the wage gain conditional on promotion to a permanent job will be greater for them. We observe a higher incidence of permanent employment among more experienced workers because they have had more opportunities to be in firms that receive a favorable productivity shock, and the exit probability from permanent jobs is relatively low.

I test the prediction that the permanent job wage premium falls as labor market experience rises using longitudinal data from the ECHP. Taking into account individual fixed effects, I find that among men the wage premium for a permanent vs. temporary job is indeed lower for older workers and native born workers; for women, the permanent job wage premium is lower for older workers and those with longer current job tenure. Moreover, there is some evidence that among immigrant men, the permanent job premium is higher for those who migrated from outside the European Union. These findings all suggest that the gain to promotion into permanent jobs is indeed higher for those with less experience in the domestic labor market; moreover, previous findings that immigrants and the young are more likely to be in temporary jobs than the native born and older workers are consistent with the view outlined above as well 
(OECD 2002; Kahn 2007). In contrast to the effects for the young and immigrants, the permanent job pay premium is slightly smaller on average for women than for men, even though on average women have less experience in the labor market than men do. It is possible that women even in permanent jobs are in segregated labor markets with a different distribution of productivity shocks from those in men's jobs. But as noted, among women, the permanent job wage premium is higher for the young and those with less current tenure, suggesting that even in the female labor market, employers pay attention to experience differences.

While these findings refer to within-person gains in pay upon attaining a permanent job, the cross-sectional pay advantage for those in permanent vs. temporary jobs is considerably higher than the fixed effects estimate. This difference suggests the importance of unmeasured factors in allocating workers between the protected and the unprotected sectors of the labor market. While the fixed effects estimates seem modest compared to other factors that affect wages such as schooling or experience, they are larger for particular subgroups such as immigrant men and the young. Consideration of the differences in this wage premium and the barriers to entry into permanent jobs thus suggests that even within groups considered to be outsiders in wage determination — the young and immigrant men — there is labor market segmentation.

Analysis of the permanent job wage premium can also reveal some sources of withingroup wage inequality. Specifically, suppose that institutions such as employment protection systems lead to a dual economy with some permanent jobs with entry barriers and some temporary jobs with easier entry. The logic of models such as those of Blanchard and Landier (2002) leads us to expect a pay premium for employment in permanent jobs, due to the workers' enhanced bargaining position occasioned by firing costs. If selection into permanent jobs is based in part on unmeasured worker skills, then these institutions will contribute to increasing wage differentials across workers with different levels of unmeasured skills. Moreover, if selection into permanent employment is made more likely by a favorable firm-specific economic 
climate, then employment protection systems will raise firm wage effects, possibly further increasing residual wage inequality.

\section{Prior Research on the Wage Premium for Permanent Jobs}

Recent research on the wage effects of permanent vs. temporary employment provides some guidance for studying its structure. For example, Stancanelli (2002) used ECHP micro data and an extensive set of controls to find hourly wage effects of permanent relative to temporary jobs across ten countries averaging 0.116 for women and 0.121 for men. Boeri (2011) used ECHP and other European microdata and found monthly wage effects for 12 of the 13 countries (i.e., all except Finland) in the current study averaging 19.3\%, although his list of controls was far less extensive than Stancanelli's (2002), and his use of monthly rather than hourly earnings may have also helped lead to his larger estimate. Specifically, Boeri (2011) controlled for education and tenure, while Stancanelli (2002) controlled for these as well as age, sector, occupation, and unemployment history.

While these estimates are suggestive, they may be upward biased because workers on permanent jobs are likely to have higher levels of unmeasured productivity than workers on temporary jobs. Supporting this idea, Booth, Francesconi, and Frank (2002) used individual panel data for Britain and found that fixed effects estimates of the permanent job premium were smaller than cross-sectional estimates. For example, the cross-sectional effect for men was 0.171

$\log$ points but the fixed effects estimate was only 0.069 ; for women, the cross-sectional estimate was 0.144 , and the fixed effects estimate was 0.109 .

In earlier work (Kahn 2012), I used the ECHP to estimate the impact of permanent jobs on hourly wages using both cross-sectional and fixed effects methods across 11 European 
countries. The controls included age, age squared, dummy variables for low (ISCED levels 0-2) and middle levels (ISCED level 3) of schooling with high levels of schooling the omitted category (ISCED levels 5-7), the regional unemployment rate, and year dummy variables. The cross-sectional estimate was $0.128 \log$ points (which is much closer to Stancanelli's (2002) estimates than Boeri's (2011) results), while the fixed effects estimate was only 0.026 log points, and both effects were statistically significant. Thus, these estimates of the wage effects of permanent jobs averaged across European countries range from a low of 0.03 (my fixed effects estimate) to a high of 0.21 (Boeri's 2011 estimate), with a middle range of 0.12-0.13 (my crosssectional estimate and Stancanelli's estimates). The smaller fixed effects estimates I found and that Booth, Francesconi and Frank (2002) found suggest that an important portion of the crosssectional estimate represents unmeasured individual heterogeneity rather than a true effect of permanent jobs. ${ }^{1}$ The individual heterogeneity can occur both across workers in the same firm and among workers across firms, since workers differ in their unmeasured skills and firms differ in the product market shocks they are affected by.

In this paper, I use fixed effects methods to investigate the structure of the permanent job wage premium. Previous work suggests that the aggregate estimate of roughly $3 \%$ is modest, certainly compared to other factors that affect wages even in countries with highly centralized wage setting mechanisms. ${ }^{2}$ Yet the small average effect may mask large differences across groups in the premium to getting a permanent job. An analysis of the structure of this premium can reveal differences in labor market outcomes within groups such as the young or immigrants.

\footnotetext{
${ }^{1}$ While not directly comparable to these worker-level estimates, Bentolila and Dolado (1994) found for five European countries (Denmark, France, Spain, West Germany, and the United Kingdom), that manufacturing wages were negatively affected by the fraction of workers on temporary contracts, a result consistent with a pay premium for permanent employees.

${ }^{2}$ For example, in such countries, the standard deviation of industry wage effects tends to be much larger than this figure, as do the effects of a one standard deviation difference in educational attainment or cognitive ability (Kahn 1998; Blau and Kahn 2005).
} 


\section{Conceptual Framework}

The basis for the empirical work to be described below comes from Blanchard and Landier's (2002) theoretical model of a labor market with both temporary and permanent jobs. These are distinguished by different levels of firing costs, with the permanent jobs of course having higher costs of termination. In this setup, all jobs start out as temporary, with low firing costs. The firm may receive a productivity shock, measured such that a higher value indicates a more favorable level of productivity, and then decides whether to promote the worker to permanent status. The authors show that there is a level of the shock - the reservation levelabove which the firm will promote and below which the firm will terminate the employment relationship. A crucial portion of the model for our purposes is the wage determination mechanism in which wages are set in a Nash bargaining framework. On both permanent and temporary jobs, firms and workers share the gains to continuing the match. These gains include the avoidance of firing costs. Since these are higher for permanent jobs, the model predicts a pay premium for those promoted into permanent jobs, which the firm will take into account before making the decision to promote the worker.

In what follows below, I generalize this framework to include the possibility that some workers (the "inexperienced") require training to enable them to perform permanent jobs and that this is acquired during employment in a temporary job. Suppose, realistically, that is more costly to fire someone from a permanent job than from a temporary job. Then an inexperienced worker's wage in a temporary job will be lowered due to the costs of getting training, and the worker will still accept the job rather than be unemployed, due to the expected benefits of training. In contrast, an experienced worker starting a temporary job is already trained, so there 
is no need for a wage discount during the temporary job. Upon promotion, the experienced and inexperienced workers are in a similar situation, since they are now both trained. The Nash bargain after promotion will thus have the same result for both inexperienced and experienced workers. Thus, the wage gain to promotion for an inexperienced worker will thus be greater than for a experienced worker. In this model, the promotion probability for the two workers in the same firm will be the same because it assumes that the inexperienced worker on a temporary job receives training before any productivity shock. However, the experienced workers will have had more chances to be promoted; we will therefore observe a higher incidence of permanent employment among experienced than inexperienced workers, since the exit probability from permanent jobs is relatively low. ${ }^{3}$

I illustrate these ideas using Blanchard and Landier's (2002) set up. Assume that a match begins between a firm and a worker who has already been trained. Suppose that all employment relationships begin with temporary jobs with firing costs $\mathrm{c}_{0}$, productivity levels for trained workers $\mathrm{y}_{0}$, and with wages (to be determined by bargaining) $\mathrm{w}_{0}$. Then assume that productivity shocks occur with probability $\lambda$ and that these shocks have cumulative distribution function $\mathrm{F}(-)$. Assume that at the point of the shock, the firm must decide whether to promote the worker to a permanent job with firing cost $\mathrm{c}$ or terminate the employment relationship. ${ }^{4}$ Let $\mathrm{y}$ be the realized productivity level of the shock, and $\mathrm{w}(\mathrm{y})$ be the wage on the permanent job. Let $\mathrm{k}$ be the cost of creating a new vacancy, $\mathrm{s}$ be the exogenous probability of retirement, and $\mathrm{r}$ be the discount rate. Then Blanchard and Landier (2002) show that there will be a reservation shock level $\mathrm{y}^{*}$ above

\footnotetext{
${ }^{3}$ As discussed further below, in the case where the inexperienced worker may not have received training before promotion, we still expect to see a larger wage gain for inexperienced than experienced workers upon promotion. ${ }^{4}$ Further following Blanchard and Landier (2002), assume that the firing costs represent administrative expenses rather than severance pay, which according to Lazear's (1990) analysis represent a transfer between the company and the worker and thus need not affect resource allocation.
} 
which the firm will promote the worker and below which the firm will terminate the employment relationship.

In this model, the flow return to the firm of a new job having value $\mathrm{V}_{0}$ is:

(1) $r V_{0}=\left(y_{0}-w_{0}\right)-c_{0} \lambda F\left(y^{*}\right)+\lambda \int_{y^{*}}^{\infty}\left[V(y)-V_{0}\right] d F(y)$

The flow value to the firm of a continuing job is:

(2) $r V(y)=[y-w(y)]+s\left[V_{0}-V(y)\right]$

The flow value of a new temporary job to an already trained worker is:

(3) $r V_{0}^{e}=w_{0}+\lambda F\left(y^{*}\right)\left(V_{u}-V_{0}^{e}\right)-s V_{0}^{e}+\lambda \int_{y_{*}^{*}}^{\infty}\left\{V^{e}[w(y)]-V_{0}^{e}\right\} d F(y)$,

where $\mathrm{V}_{\mathrm{u}}$ is the value of being unemployed and $\mathrm{V}^{\mathrm{e}}(\mathrm{w}(\mathrm{y}))$ is the value of a permanent job with productivity level y. Finally, the flow return to the worker of being employed in a permanent job is:

(4) $r V^{e}[w(y)]=w(y)-s V^{e}[w(y)]$.

With these value functions, assume Nash bargaining for both temporary and permanent jobs. For permanent jobs, the firm's status quo value is $\mathrm{V}_{0}-\mathrm{c}$, which is the value of posting a new vacancy minus the firing costs, while the worker's status quo value is $V_{u}$, the value of being unemployed. For temporary jobs, the firm's status quo value is $\mathrm{V}_{0^{-}} \mathrm{c}_{0}$, which is the value of 
creating a new vacancy minus the firing cost from a temporary job, while the worker's status quo value is still $\mathrm{V}_{\mathrm{u}}$. The reservation productivity $\mathrm{y}^{*}$ is defined implicitly as:

(5) $V\left(y^{*}\right)=V_{0}-c_{0}$.

That is, the reservation productivity makes the firm indifferent between promoting the worker into a permanent job and firing the worker, paying the temporary job firing costs and announcing a new vacancy.

With symmetric Nash bargaining, we have the following conditions for the worker's value of temporary and permanent jobs:

(6) $V_{0}^{e}-V_{u}=c_{0}$ and

(7) $V^{e}[w(y)]-V_{u}=V(y)-V_{0}+c .^{5}$

Thus, the worker's gain to promotion into a job with productivity y is:

(8) $V^{e}[w(y)]-V_{0}^{e}=V(y)-V_{0}+c-c_{0}=V(y)-V\left(y^{*}\right)+c$

and the worker's expected gain to promotion given a promotion is:

(9) $E\left\{V^{e}[w(y)]-V_{0}^{e} \mid y \geq y^{*}\right\}=E\left[V(y)-V\left(y^{*}\right)+c \mid y \geq y^{*}\right]$.

\footnotetext{
${ }^{5}$ As explained by Blanchard and Landier (2002), the left hand sides of equations (6) and (7) represent the worker's
} gain to, respectively, a temporary and a permanent job, while the right hand sides are the firm's corresponding gains. 
Using this framework, we can now contrast the gains to promotion for experienced vs. inexperienced workers. Under my assumptions about timing, the only difference between hiring an experienced vs. an inexperienced worker is that the firm must pay training costs for the latter at the beginning of the temporary job. Denote these costs as H. Thus, the net productivity for hiring an inexperienced worker is $\left(\mathrm{y}_{0}-\mathrm{H}\right)$. In this setup, we must modify the firm's and worker's values of a temporary job relative to hiring an experienced worker. Under competition, the value to the firm of hiring an inexperienced or an experienced worker for the temporary job must be the same. Since the inexperienced worker is instantaneously trained, the promotion decision becomes identical for the two types of workers and so does the status quo income given promotion. Thus, the only way for the firm to be indifferent between hiring an experienced vs. and inexperienced worker is for the latter to accept a wage that is reduced by the full training costs (the usual general human capital result). Thus, the inexperienced worker gains more upon promotion than the experienced worker.

The scenario outlined above assumes that the inexperienced worker receives training instantaneously upon being hired into the temporary job. If training is not instantaneous, it is possible that a productivity shock could occur before the worker is trained. Even in such a scenario, the more experienced worker is more likely to have been trained before starting a temporary job than a less experienced worker. If one can only be promoted upon receiving training and a favorable productivity draw, then the less experienced worker will have a larger expected gain in wages upon promotion than the more experienced worker. Alternatively, it may be possible for one to be promoted before being trained. Of course, for such a decision to be profitable for the firm, the productivity shock threshold needs to be higher for a currently untrained worker than a currently trained worker. In such a case, the firms which promote inexperienced workers will have had on average more favorable draws than those which promote 
more experienced workers, and this difference in firm selectivity will tend to raise the observed return to promotion for inexperienced relative to that for experienced workers. This is the case because promotion for the untrained worker also entails training, which raises the value of unemployment; in contrast, for a trained worker, the value of unemployment stays the same upon promotion.

\section{Data and Descriptive Patterns}

I use the ECHP data for 1995-2001 for the following countries to study the impact of temporary employment contracts on job search: Austria, Belgium, Denmark, Finland, France, Germany, Greece, Ireland, Italy, the Netherlands, Portugal, Spain, and the United Kingdom. ${ }^{6}$ This is a panel data base that follows individuals over the 1994-2001 period. The questions were harmonized as much as possible in order to produce a data base that would provide comparable information across countries. ${ }^{7}$ Beginning in 1995 for all of these countries except Finland and in 1996 for Finland, the ECHP asked each employed wage and salary worker whether his/her job was characterized by a fixed term contract. Specifically, each employed respondent is asked: "What type of employment contract do you have in your main job?" The possible responses are: 1) permanent employment; 2) fixed-term or short-term contract; 3) casual work or no contract; 4) some other working arrangement. I include only those with responses 1) or 2), that is, those that state they have a permanent or a temporary employment contract.

Table 1 shows mean values for the incidence of temporary employment among wage and salary workers by country and gender, for ages 16-65. The figures are weighted using the ECHP's sampling weights which I adjusted so that each country receives the same total weight. About $9-11 \%$ of the sample has a temporary contract. Moreover, women have a higher

\footnotetext{
${ }^{6}$ Of the fifteen countries in the ECHP, these are the only ones with data on contract type (i.e., permanent vs. temporary), with repeated observations on the same person, and complete data on the explanatory variables.

7 For further description of the methods and sample characteristics of the ECHP, see the Eurostat web site: http://circa.europa.eu/irc/dsis/echpanel/info/data/information.html .
} 
incidence of temporary employment in each country than men do, and temporary jobs are especially prevalent in Spain. Finland and Portugal also have a relatively high incidence of temporary jobs as well. ${ }^{8}$

Table 2 shows the mean of the log of hourly earnings expressed in purchasing power parity units in 2001 US dollars by country, gender and contract type. ${ }^{9}$ In all cases except for women in the United Kingdom (where pay is the same across contract type) permanent jobs pay more than temporary jobs, usually considerably so. For example, for men, there is an average $0.325 \log$ point gap favoring permanent jobs, while for women, the average permanent job wage advantage gap is $0.245 \mathrm{log}$ points. France, Spain and the Netherlands show especially large pay gaps favoring permanent contracts. Of course, Table 2 doesn't control for individual measured characteristics such as human capital or sector, and it also doesn't adjust for unmeasured person effects. The next section describes the regression design that attempts to estimate the effect of obtaining a permanent job at the individual level.

\section{Empirical Procedures and Regression Results}

The basic empirical setup for testing the predictions about the wage impact of permanent employment is to estimate the following individual fixed effects model of the determinants of the log of hourly earnings:

\footnotetext{
${ }^{8}$ Earlier work has shown that the ECHP data on the incidence of temporary employment contracts match up well with published sources such as the OECD. See Kahn (2010).

9 The ECHP provides purchasing power parity rates for each country in each year, allowing one to transform the earnings data into US purchasing power units for that year. These transformed earnings variables were then corrected for US inflation by using the Personal Consumption Expenditures deflator for the US, taken from www.bea.gov. I excluded observations with hourly earnings less than \$1 or greater than \$300 in 2001 purchasing power parity units. These exclusions amounted to about $0.2 \%$ of the sample.
} 
(10) ln wage $=f($ age, agesq, edlow, edmid, tenure, tenuresq, temp, temp*age, temp*agesq, temp*immigrant, temp*edlow, temp*edmid, temp*tenure, temp*tenuresq, industry dummies, regional unemployment rate, occupation dummies, year dummies, u),

where for each employed wage and salary worker ln wage is the log of hourly earnings (defined above), age is age in years, edlow and edmid are, respectively, dummy variables for low (ISCED levels 0-2) and middle levels (ISCED level 3) of schooling with high levels of schooling the omitted category (ISCED levels 5-7), temp is a dummy variable for a temporary employment contract, immigrant is a dummy variable equaling one if the respondent was either born in a foreign country or is not a citizen, tenure is number of months of tenure with one's current employer, and $\mathrm{u}$ is a disturbance term. ${ }^{10}$ Equation (10) was estimated separately for men and women pooling the data across countries with the standard errors clustered by country. I use the ECHP sampling weights adjusted so that each country receives the same weight. Since I use individual fixed effects, time-invariant variables such as country dummies or immigrant status are not included. In addition, in some supplementary analyses, I estimate equation (10) separately by country and gender with standard errors clustered at the individual level.

The key explanatory variables in (10) are those relating to temporary employment, specifically, its main effect and its interactions with age, age squared, tenure, tenure squared, and immigration status. I also include interactions with the education variables, although the theory outlined above doesn't distinguish across levels of formal schooling. The theoretical analysis predicts that temporary employment will have positive interaction effects with age and tenure, and a negative interaction effect with the immigrant dummy variable on the idea that the young, those recently hired, and immigrants have less experience in the domestic labor market or the current firm than older workers, those with longer tenure, and natives. Since women have less labor market experience than men, the same reasoning predicts that the women will face a larger

\footnotetext{
10 As discussed below, combining non-citizens and those born in another country into one category is necessary in order to use the sample of 13 countries shown in Tables 1 and 2. Also as discussed below, I additionally in some analyses restrict the models to countries with information on the respondent's birthplace.
} 
discount in temporary vs. permanent jobs than men do. However, to the extent that there is occupational or industrial segregation by gender, even permanent jobs for women may not be as well protected or as relatively high paying as those for men.

The controls in equation (10) include basic human capital variables, tenure, industry and occupation (see the Appendix for the actual industry and occupation categories), as well as the regional unemployment rate. Regional unemployment rate information was collected from the European Labour Force Survey and matched to the regional indicators in the ECHP data. ${ }^{11}$ Because employment in a temporary job can affect one's future industry, occupation and job tenure, I also estimate the basic model excluding these variables. Such estimates can be viewed as reduced forms of the impact of temporary employment relative to permanent employment. In addition, to abstract from school and retirement issues, I also estimated the basic model for those age 19-60. The results, available on request, were very similar to those reported for the full sample of 16-65 year olds.

As mentioned, immigrants are defined as those who were either born in a foreign country or are not citizens. The ECHP has enough information to define variable this for each of the 13 countries in Tables 1 and 2. However, to focus further on the immigrant labor market, I analyze a subset of countries for which the ECHP has data on the respondent's birthplace and time since migration to the current country. These include Belgium, Denmark, France, Ireland, Portugal, and Spain. ${ }^{12}$ On this subsample, I am able to test whether the impact of being in temporary job differs depending on whether one was born in a foreign country in the European Union or outside the European Union. Moreover, I also test whether time in the current country affects the returns to a permanent vs. a temporary job. The logic of the model described earlier implies that the wage effect of a permanent job should be greater for those born outside of the EU and for

\footnotetext{
11 I am grateful to Alison Davies and Rhys Powell for their help in acquiring the European Labour Force Survey regional unemployment rate data. Since the ECHP did not collect regional information for Denmark or the Netherlands, I used the national unemployment rate for those countries.

12 I exclude the United Kingdom from this analysis because the number of respondents for whom the foreign birthplace is identified is too small. Specifically, there were only 90 such individuals in the United Kingdom sample, compared to 318-1913 in each of the six countries analyzed.
} 
more recent migrants. Unlike much research on immigrant assimilation profiles, the ECHP allows one to follow the same immigrant over time. However, there may still be a bias in estimating such profiles to the extent that there is selective outmigration (Lubotsky 2007).

Tables 3 and 4 contain basic individual fixed effects regression results for the determinants of the log of hourly earnings for the pooled sample of 13 countries, separately for men and women (Appendix Tables A1 and A2 contain results separately by country and gender). Column (1) of Tables 3 and 4 shows the effects of employment in a temporary job without controlling for industry, occupation, tenure or for interactions between temporary employment and other variables. The effect is -0.0322 for men and -0.0149 for women, with both effects significant. The corresponding Ordinary Least Squares (OLS) estimates, with country dummies and an immigrant dummy additionally included, are -0.1435 (standard error 0.0315) for men and -0.1146 (standard error 0.0263 ) for women. Recall from Table 1 that the mean differential between wages in permanent and temporary jobs was $0.325 \log$ points for men and $0.245 \log$ points for women, which are substantially larger than the OLS regression coefficients in magnitude. Thus, most of the difference in the mean wages between permanent and temporary jobs is due to individual characteristics, with both measured and unmeasured characteristics having an important effect. But the fixed effects results in Tables 3 and 4 do indicate at least a modest return to a permanent job for both men and women, with a slightly larger effect for men.

Columns (2) and (3) of Tables 3 and 4 show that the estimated return to a permanent job largely holds up when I control for current tenure and also industry and occupation. Specifically, the temporary employment coefficient with controls for tenure, industry and occupation included is $82-89 \%$ as large in absolute value as it is without these additional controls, although the effect for women now just misses being statistically significant. The male result remains significant, however. The column (3) results suggest that there is a modest average return to permanent employment controlling for tenure, industry and occupation, as well as unmeasured person effects. 
Columns (4)-(6) show the results of the key interactions between temporary employment and age, immigrant status, and current job tenure. The results are qualitatively similar for men and women. Specifically, temporary employment has less negative effects on the wages of older workers, non-immigrants and those with longer current tenure. Each of these results was predicted by reasoning outlined earlier about training, temporary employment and permanent employment. For men, the temporary employment interactions with the age variables and immigrant status are significant, while for women the interactions with age and tenure are significant. To illustrate the magnitude of these interaction effects, consider the fully specified model in column (6) of Tables 3 and 4. For men, the interactions between temporary employment and age imply that the impact of permanent employment is about $0.10 \log$ points more negative at age 16 than at the mean age of 39 years, while for women temporary employment has an effect on wages that is about $0.06 \log$ points more negative at age 16 than at the mean age of $37 .^{13}$ Column (6) of Tables 3 and 4 implies that interaction effects with tenure are smaller in magnitude than those with age: for men, the wage effect of temporary employment is $0.0044 \log$ points more negative at zero tenure than at two years' tenure, a long duration for a temporary job (Kahn 2012); for women, the effects of a temporary job $0.0123 \log$ points more negative at zero tenure than at two years' tenure. Moreover, as predicted, temporary employment has more negative effects for immigrants with effects of -0.059 for men and -0.0365 for women. All told, the impact of getting a permanent job is moderately higher for those with less experience in the domestic labor market or firm. Combining the interaction effects for age, immigrant status and tenure, we can conclude that young immigrant men just starting their jobs have a $0.16 \log$ points higher return to getting a permanent job than natives of average age with two years of current tenure; for women, the corresponding exercise yields an effect of $0.11 \log$ points.

\footnotetext{
${ }^{13}$ For comparison purposes, the log wage effect of a temporary job relative to a permanent job for non-immigrant men with zero tenure and a high level of schooling is -0.02 , while it is -0.013 for similar women.
} 
In addition to these interaction effects, Tables 3 and 4 also contain information about the impact of temporary employment by education level and gender. For men, the less educated and those with a middle level of schooling have a modestly smaller return to getting a permanent job (.01-.03 log points) than those with high levels of schooling (i.e. the interactions temp*edlow and temp*edmid have positive coefficients, with the interactions with low schooling levels being significant). The higher return to getting a permanent job for well-educated men could reflect the type of temporary jobs they may have been in, which may have had a substantial training component with its attendant low wages. For women, however, these interactions are very small in magnitude and insignificant.

As noted, the return to getting a permanent job is on average slightly larger for men than women, even though the basic model implied that those with less experience should receive a higher return to permanent employment. Since women on average have less experience than men, one might have expected a higher return to permanent employment for women than for men. However, to the extent that there are glass ceilings in employment for women, wages in permanent jobs may constrained for them (Arulampalam, Booth, and Bryan 2007). I note that the slightly larger male permanent job wage effect persists after controlling for largely one digit industry and occupation (column 3 of Tables 3 and 4); thus, for the glass ceiling phenomenon to explain this difference, there must be gender segregation within these categories, a plausible result. For example, Anker (1998, p. 102) found that for a sample of OECD countries with data from roughly 1990 the gender occupational segregation index was 0.38 when occupations were defined at the one digit level but fully 0.63 when they were defined at the three digit level. ${ }^{14}$ Thus, it is possible that women are on a different track from men. However, among women, the least experienced still obtain the highest return to promotion to a permanent job.

Appendix Tables A1 and A2 show selected results separately by country and gender. The overall findings are similar to the results pooled across countries as shown in Tables 3 and 4,

\footnotetext{
${ }^{14}$ The gender occupational segregation index (or index of dissimilarity) is the fraction of women or men who would have to change jobs in order to achieve perfect gender integration.
} 
although the coefficients are less statistically significant when the model is disaggregated by country. For each country-gender sample, two models are shown: one with just the basic controls including age, age squared, edlow, edmid, and year dummies, and one fully specified model with all interactions, industry and occupation. Looking at the model with just the temporary employment dummy variable and these controls, one sees that for men, the effect of a temporary job is negative 12 of 13 times, with four of these effects significant. The one positive effect (Ireland) is not significant. For women, eight of the 13 estimates are negative, with four of these significant. None of the positive effects is significant. The average effect is -0.024 for men and -0.015 for women; recall that the effects pooling the countries as shown in Tables 3 and 4 were -0.032 for men and -0.015 for women.

Figures 1 and 2 show the effect of a permanent job (i.e. minus one times the temp coefficient) from this specification by the OECD's index of permanent (Figure 1) or temporary (Figure 2) employment regulation strictness for the late 1990s (taken from OECD 2004, p. 117). The coefficients for men and women from Tables A1 and A2 are pooled, yielding 26 observations. Figure 1 shows that the return to a permanent job is positively correlated with the strictness of permanent employment regulation, although the relationship is not statistically significant. This pattern is predicted by Blanchard and Landier's (2002) model in which the reservation productivity rises when firing costs from permanent jobs rise. However, Figure 2 shows an unexpectedly positive, though weaker, relationship between the return to a permanent job and the temporary employment regulation strictness. ${ }^{15}$ When I regressed the permanent job wage premium on both OECD indicators and a gender dummy variable for the sample, I obtained the following coefficients with standard errors in parentheses:

permanent job log wage effect $=.0041(.0175)+.0067(.0068)$ oecdperm +.0018 (.0043) oecdtemp -.0086 (.0107) female, with an $\mathrm{R}^{2}$ of .0912,

\footnotetext{
${ }^{15}$ Some earlier research on the determinants of contract type has also failed to find predicted effects of the OECD's index of temporary employment regulation strictness (Booth, Dolado and Frank 2002; Kahn 2007).
} 
where oecdperm and oecdtemp are, respectively, the OECD's indicators of permanent and temporary job regulation strictness for the late 1990s on a six point scale. The regression shows positive coefficients for both types of regulation, with a larger effect for permanent regulation. The regression implies that moving from the UK's level of permanent employment regulation (at 0.9 the lowest of the 13 country sample) to Portugal's (the strictest regulation, with an index of 4.3) raises the return to a permanent job by .023 log points, a large effect relative to the average. However, a similar exercise for temporary employment regulation (i.e. moving from the UK's level of 0.3 to Greece's level of 4.8 , which are the extremes for the 13 country sample for temporary employment regulation) raises the wage return to a permanent job by $0.0081 \log$ points. Thus, the regression implies that raising both types of regulation simultaneously from the least to the most restrictive level raises the return to a permanent job by 0.015 log points. ${ }^{16}$

Tables A1 and A2 also show results for the interactions between temporary employment and age, education, immigrant status and tenure. While the results are less statistically significant than the pooled results shown in Tables 3 and 4, the basic patterns are similar. Specifically, among men, temporary jobs have a less negative effect on wages for older workers in 11 of the 13 countries analyzed, with several of the positive temporary employment-age interactions statistically significant. Among women, temporary jobs have a less negative effect on older workers' wages in 10 of 13 countries, again with some of these positive age interactions significant. Of the few negative age-temporary employment interactions, only for men in Greece is the effect statistically significant. ${ }^{17}$

Tables A1 and A2 show that temporary employment had negative interaction effects for immigrants in 10 of 13 countries and for women in 9 of 13 countries. The negative interaction

\footnotetext{
${ }^{16}$ In both Figures 1 and 2, the regression line has a positive slope but is insignificant. As pointed out by Bentolila, Cahuc, Dolado and Le Barbanchon (2012), a perhaps more relevant indicator of the effects of permanent and temporary employment regulation is to compute the difference in firing costs between the two types of jobs. However, the OECD's employment protection indicators don't allow such a difference to be meaningfully computed.

${ }_{17}$ Joint significance tests for the temp*age and temp*age squared interactions yielded statistical significance among men in France, Ireland, Portugal and Spain, while for women, they were jointly significant in Austria.
} 
effects were statistically significant five times for men and twice for women, and none of the positive interaction effects was significant. Thus, overall, obtaining a permanent job has larger positive effects for immigrants than non-immigrants. Below, I provide some more detail on the impact of temporary employment for immigrants, including effects of region of origin and time in the current country.

Finally, the temporary employment-tenure interactions are less consistent than the age or immigrant interactions. Among men, six of the countries have positive interactions, while seven have negative interactions; in four cases, the two tenure interactions are jointly significant—once for a positive effect and three times for a negative effect. Thus, for men, there is little overall evidence that the return to temporary employment is affected by tenure, as implied by the pooled results in Table 3. However, for women, nine of the 13 tenure interaction effects in Table A2 are positive, and of these, four of the tenure interaction pairs are jointly significant. None of the pairs for the negative results are jointly significant. Thus, as was the case in the pooled analyses of Table 4, the disaggregated results for women shown in Table A2 suggest that the return to a permanent job is indeed less for women with longer current tenure, as predicted by the training model.

Up to now, I have included all countries with data on the key variables and defined immigrant as either being foreign born or not being a citizen. For a subsample of the ECHP countries, one can discern the respondent's actual birthplace, allowing for a more detailed look at the role of immigration. These countries include Belgium, Denmark, France, Ireland, Portugal and Spain. Tables 5 and 6 show fixed effects log hourly earnings results for these countries where I take a more detailed look at immigration than is possible in the full sample of 13 countries. Specifically, it is possible for the subset in Tables 5 and 6 to study the role of being foreign born inside vs. outside the European Union (EU) as well as the role of time in the current country. I expect that immigrants born in the EU and those who have been in the current country for a longer time to have better knowledge about employment practices than immigrants born outside the EU or who have recently arrived. Using the same logic as discussed earlier, I expect 
a smaller return to permanent employment for immigrants born in the EU vs. outside the EU as well as for immigrants with more years since migration (ysm). ${ }^{18}$ The findings for men shown in Table 5 largely support these hypotheses; however, for women, the results shown in Table 6 do not support these hypotheses about immigrants.

First, looking at the male results in Table 5, column 2 shows that the effect of a temporary job for those born outside the $\mathrm{EU}$ is $0.17 \log$ points more negative than for the native born, a statistically significant result that is large in magnitude. Moreover, the effect of being foreign born for those born within the EU is $0.15 \mathrm{log}$ points more positive than this result, a difference that is also statistically significant. In fact, relative to the native born, being foreign born within the EU leads to a temporary job wage effect that is only 0.022 log points more negative (i.e. the sum of the temp*foreignborn and temp*foreignborn in the EU coefficients), a difference that is not statistically significant. Thus, regarding the gains to permanent employment, foreign born males who originated from within the EU resemble the native born much more closely than they do foreign born males originating from outside the EU. Moreover, the wage disadvantage of a temporary job is less the longer a foreign born male has been in the current country, although the temp*ysm and temp*ysm squared coefficients are not significant individually or as a pair. As was the case for the full sample of 13 countries, the effect of a temporary job continues to be significantly less negative for older men in the subsample of six countries shown in Table 5. However, the tenure interactions are small, insignificant and opposite in sign to what I found for the larger sample. Finally, adding further interactions between ysm and ysm squared and being born in a foreign EU country led to statistically insignificant results.

For women, Table 6 shows very small and statistically insignificant interaction effects between temporary employment and being foreign born as well as temporary employment and being foreign born from the EU. Moroever, temporary employment actually has a negative

\footnotetext{
${ }^{18}$ Since I estimate individual fixed effects models using the longitudinal feature of the ECHP data, the analysis of ysm doesn't suffer from "single cross-section" problem identified by Borjas (1985); however, the results for ysm, as noted earlier, may be affected by selective outmigration.
} 
interaction effect with ysm. While the temp*ysm interaction is marginally significant, the two interactions together are not significant in either column (4) or column (5) of Table 6 . In addition, as was the case for men, adding further interactions between ysm and ysm squared and being born in a foreign EU country led to statistically insignificant results. Thus, for women, our hypotheses about immigration are not borne out. It is possible that labor force selection issues are more salient for immigrant women than immigrant men, and these could have masked an effect of getting a permanent job for immigrants. But even for this subsample of six countries, the age and tenure interactions with temporary employment for women are similar to what they were in the full sample of 13 countries.

\section{Conclusions}

In this paper, I have used ECHP data to investigate the premium workers command in permanent jobs relative to temporary jobs across thirteen European countries. A basic framework to understand this issue comes from Blanchard and Landier's (2002) research in which it is assumed that firms start workers in temporary jobs. In the presence of higher firing costs for permanent jobs relative to temporary jobs, firms will be reluctant to promote workers unless the economic circumstances of the firm warrant it. Once promoted, workers are able to appropriate some of the firing costs, since these raise the value of continuing the employment

match once the worker is promoted. Thus, an important determinant of the wage premium in a permanent job is the value of the match relative to breaking it up and starting over with a temporary employee.

I hypothesized that before being promoted into a permanent job, inexperienced workers must receive training in the temporary job to which they have been hired. In equilibrium, their starting wages in the temporary job will be below the level of starting wages for experienced, trained workers starting a temporary job. Because of the wage discount at the beginning of the temporary job for less experienced workers, the wage gain conditional on promotion to a 
permanent job will be greater for them. In this framework, we expect to observe a higher incidence of permanent employment among more experienced workers because they have had more opportunities to be in firms that receive a favorable productivity shock, and the exit probability from permanent jobs is relatively low.

I tested the prediction that the permanent job wage premium falls as labor market experience rises using longitudinal data from the ECHP. Taking into account individual fixed effects, I found that among men the wage premium for a permanent vs. temporary job is indeed significantly lower for older workers and native born workers; for women, the wage premium for a permanent job was found to be lower for older workers and those with longer current job tenure. Moreover, there is some evidence that the wage return to a permanent job was especially high for immigrant men born outside of the European Union; in contrast, the premium was much smaller for those born within the EU. These findings all suggest that the gain to promotion into permanent jobs is indeed higher for those with less experience in the domestic labor market; moreover, previous findings that immigrants and the young are more likely to be in temporary jobs than the native born and older workers are consistent with the view outlined above as well (OECD 2002; Kahn 2007).

An implication of these results is that policies that contribute to dual labor market structures consisting of a protected, permanent sector and an unprotected, temporary sector also contribute to within group current measured wage inequality, particularly for young women and men, immigrant men, and recently hired women. However, lifetime within group wage inequality may be less affected to the extent that training on temporary jobs leads to permanent employment. Nonetheless, given the current stagnation in European labor markets and the extremely high rates of unemployment among youth in several countries, ${ }^{19}$ it may take a long time before new entrants can realize the gains to being promoted into protected jobs.

\footnotetext{
${ }^{19}$ For example, among males age $15-24$, unemployment rates in 2012 were $48.4 \%$ in Greece, $33.7 \%$ in Italy, $36.4 \%$ in Portugal, and 54.4\% in Spain; for females in this age group, the corresponding figures were $63.2 \%$ if Greece, $37.5 \%$ in Italy, 39.2\% in Portugal, and 51.8\% in Spain. See OECD (2013), pp. 246-7.
} 


\section{Appendix: Occupation and Industry Dummy Variables Categories}

\section{Occupations}

Legislators, senior officials and corporate managers

Managers of small enterprises and other managers

Physical, mathematical, life science, health and engineering science professionals

Teaching professionals

Other professionals

Associate professionals (technicians in physical, engineering, life and health sciences)

Teaching associate professionals and other associate professionals

Clerical workers

Personal service workers

Sales workers

Skilled agricultural and fishery workers

Craft workers

Operatives

Elementary occupations (the omitted category from the regressions)

\section{Industries}

Agriculture, forestry and fishing

Mining, electricity, gas and water supply

Nondurable manufacturing

Durable and other manufacturing

Construction

Wholesale and retail trade

Hotels and restaurants

Transport, storage and communications

Finance

Real estate

Public administration

Education

Health and social work

Other community, social and personal services (the omitted category from the regressions) 


\section{References}

Anker, Richard. 1998. Gender and jobs: Sex segregation of occupations in the world. ILO: Geneva.

Arumlampalan, W., Booth, A.L., Bryan, M. L. 2007. Is there a glass ceiling over Europe? Exploring the gender pay gap across the wage distribution. Industrial \& Labor Relations Review 60, no. 2 (January): 163-187.

Bentolila, S., Cahuc, P., Dolado, J. J., Le Barbanchon, T. 2012. Two-tier labor markets in the Great Recession: France vs. Spain. Economic Journal 122, no. 562 (August): F155F187.

Bentolila, S., Dolado, J.J. 1994. Labour flexibility and wages: Lessons from Spain. Economic Policy 9, no. 18 (April): 53-85.

Blau, F. D., Kahn, L.M. 2005. Do cognitive test scores explain higher US wage inequality?” The Review of Economics and Statistics 87, no. 1(February): 184-193.

Blanchard, O., Landier, A. 2002. The perverse effects of partial labour market reform: Fixedterm contracts in France. Economic Journal 112, no. 480 (June): F214-F244.

Boeri, T. 2011. Institutional reforms and dualism in European labor markets. In: Ashenfelter, O., Card, D. (Eds), Handbook of labor economics, Volume 4B. Elsevier: Amsterdam, 1173-1236.

Booth, A.L., Dolado, J.J, Frank, J. (2002). Symposium on temporary work introduction. Economic Journal 112, no. 480 (June): F181-F188.

Booth, A. L., Francesconi. M., Frank, J. 2002. Temporary jobs: stepping stones or dead ends. Economic Journal 112, no. 480 (June): F189-F213.

Borjas, G. J. 1985. Assimilation, changes in cohort quality, and the earnings of immigrants. Journal of Labor Economics 3, no. 4 (October): 463-489.

Cahuc, P., Postel-Vinay, F. 2002. Temporary jobs, employment protection and labor market performance. Labour Economics 9, no. 1 (February): 63-91.

Kahn, L. M. 1998. Collective bargaining and the interindustry wage structure: International evidence. Economica 65, no. 260 (November): 507-534.

Kahn, L.M. 2007. The impact of employment protection mandates on demographic temporary employment patterns: International microeconomic evidence. Economic Journal 117, no. 521 (June): F333-F356.

Kahn, L. M. 2010. Employment protection reforms, employment and the incidence of temporary jobs in Europe: 1996-2001. Labour Economics 17, no. 1 (January): 1-15.

Kahn, L. M. 2012. Temporary jobs and job search effort in Europe. Labour Economics 19, no. 1 (January): 113-128. 
Lazear, E. P. 1990. Job security provisions and employment. Quarterly Journal of Economics 105, no. 3 (August): 699-726.

Lubotsky, D. 2007. Chutes or ladders? A longitudinal analysis of immigrant earnings. Journal of Political Economy 115, no. 5 (October): 820-867.

OECD. 2002. Employment outlook. OECD: Paris.

OECD. 2004. Employment outlook. OECD: Paris.

OECD. 2013. Employment. OECD: Paris.

Stancanelli, E.G.F. 2002. Do temporary jobs pay? Wages and career perspectives of temporary workers. Working paper, Tilburg University. 


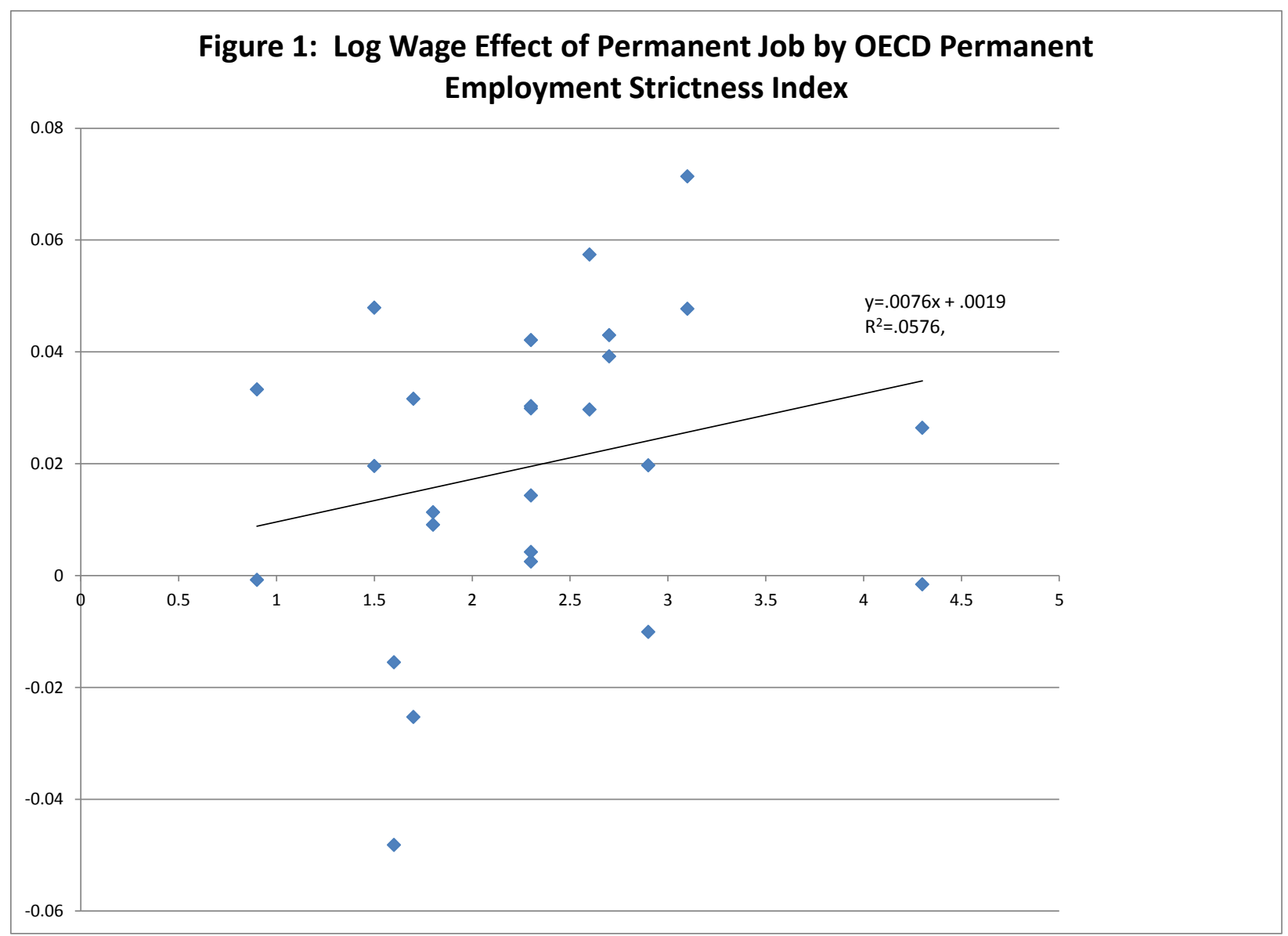


Figure 2: Log Wage Effect of Permanent Job by OECD Temporary Employment Strictness Index

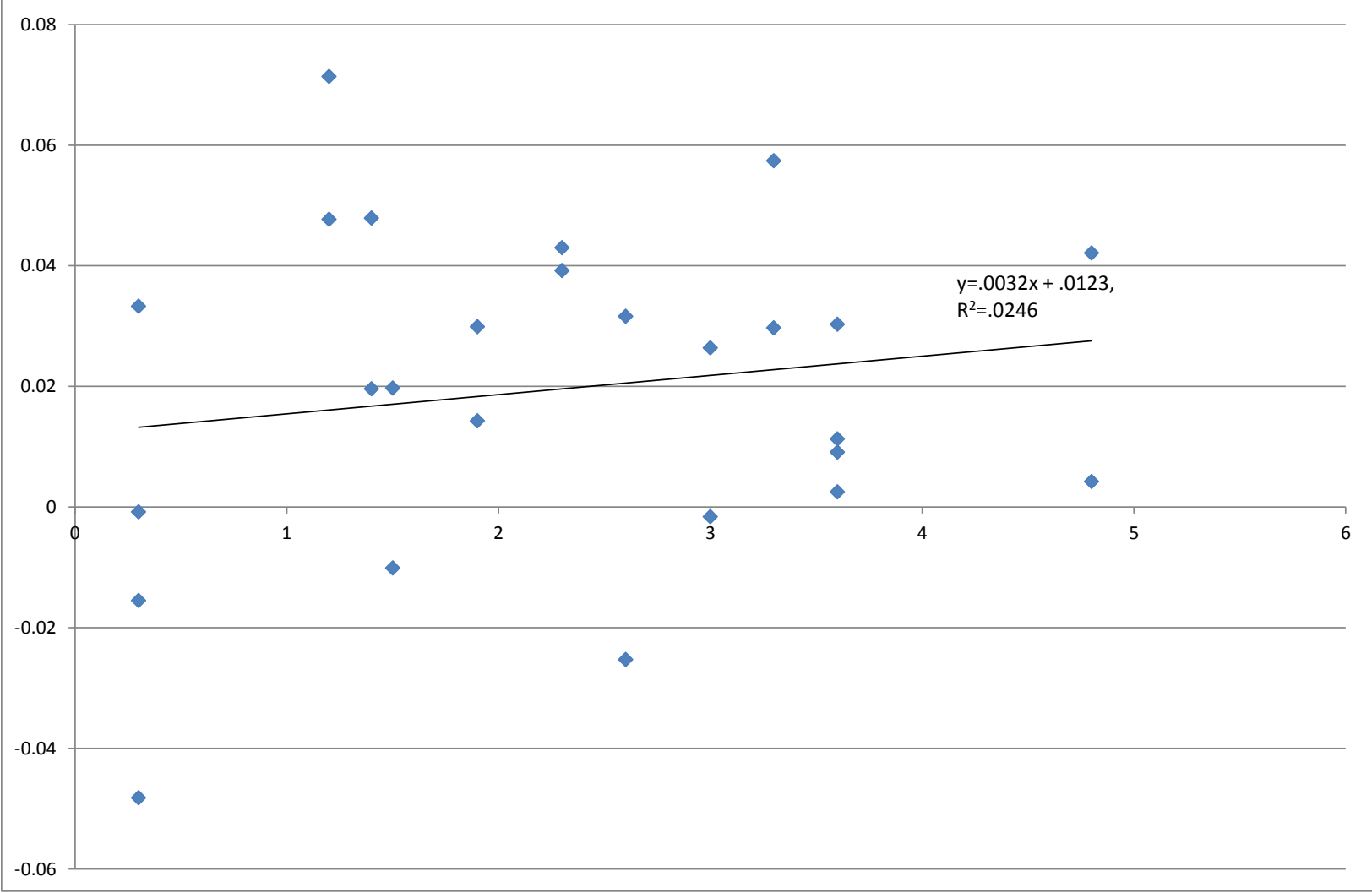

28 
Notes to Figures 1 and 2. The Figures graph on the vertical axis the log wage coefficient of temporary employment for a given country-gender sample, taken from the wage equations in Tables A1 (men) and A2 (women) without the temporary employment interaction terms. On the horizontal axis is OECD's (2004) indicator of permanent employment (Figure 1) or temporary employment (Figure 2) regulation strictness for the late 1990s. 
Table 1: Temporary Employment as a Fraction of Total Employment, Wage and Salary Workers

Men Women

Incidence Sample Size Incidence Sample Size

\begin{tabular}{lcccc}
\hline Austria & 0.045 & 10251 & 0.060 & 7212 \\
Belgium & 0.075 & 5120 & 0.132 & 4267 \\
Denmark & 0.041 & 6032 & 0.065 & 5830 \\
Finland & 0.120 & 6502 & 0.175 & 6641 \\
France & 0.080 & 14981 & 0.093 & 12548 \\
Germany & 0.063 & 18207 & 0.089 & 13266 \\
Greece & 0.078 & 8589 & 0.105 & 5325 \\
Ireland & 0.040 & 7818 & 0.074 & 5588 \\
Italy & 0.066 & 17201 & 0.081 & 11095 \\
Netherlands & 0.027 & 14053 & 0.050 & 9518 \\
Portugal & 0.101 & 14191 & 0.145 & 10771 \\
Spain & 0.304 & 17882 & 0.326 & 9615 \\
UK & 0.034 & 12759 & 0.037 & 12297 \\
& & & & \\
Total & 0.085 & 153586 & 0.108 & 113973 \\
\hline
\end{tabular}

Source: ECHP, 1995-2001. Sample weights are adjusted so that each country receives the same total weight. 
Table 2: Mean Log Hourly Earnings, Permanent and Temporary Jobs, Wage and Salary Workers

\begin{tabular}{|c|c|c|c|c|c|c|c|c|c|}
\hline \multicolumn{5}{|c|}{ Men } & \multicolumn{5}{|c|}{ Women } \\
\hline Perman & nt Job & Tempor & ary Job & Difference & Perman & ent Job & Tempor & ary Job & Difference \\
\hline Mean Log & & Mean Log & & & Mean Log & & Mean Log & & \\
\hline $\begin{array}{l}\text { Hourly } \\
\text { Earnings }\end{array}$ & $\begin{array}{l}\text { Sample } \\
\text { Size }\end{array}$ & $\begin{array}{l}\text { Hourly } \\
\text { Earnings }\end{array}$ & $\begin{array}{c}\text { Sample } \\
\text { Size }\end{array}$ & $\begin{array}{l}\text { (Perm- } \\
\text { Temp) }\end{array}$ & $\begin{array}{l}\text { Hourly } \\
\text { Earnings }\end{array}$ & $\begin{array}{c}\text { Sample } \\
\text { Size }\end{array}$ & $\begin{array}{l}\text { Hourly } \\
\text { Earnings }\end{array}$ & $\begin{array}{l}\text { Sample } \\
\text { Size }\end{array}$ & $\begin{array}{l}\text { (Perm- } \\
\text { Temp) }\end{array}$ \\
\hline
\end{tabular}

\begin{tabular}{|c|c|c|c|c|c|c|c|c|c|c|}
\hline Austria & 2.031 & 9849 & 1.837 & 402 & 0.194 & 1.842 & 6769 & 1.740 & 443 & 0.103 \\
\hline Belgium & 2.096 & 4769 & 1.882 & 351 & 0.214 & 2.024 & 3707 & 1.913 & 560 & 0.111 \\
\hline Denmark & 2.152 & 5769 & 1.984 & 263 & 0.167 & 2.069 & 5448 & 1.943 & 382 & 0.127 \\
\hline Finland & 1.888 & 5743 & 1.714 & 759 & 0.174 & 1.759 & 5460 & 1.630 & 1181 & 0.129 \\
\hline France & 2.167 & 13778 & 1.732 & 1203 & 0.435 & 2.042 & 11293 & 1.626 & 1255 & 0.416 \\
\hline Germany & 2.138 & 17061 & 1.846 & 1146 & 0.293 & 1.870 & 12054 & 1.722 & 1212 & 0.148 \\
\hline Greece & 1.801 & 7867 & 1.597 & 722 & 0.204 & 1.645 & 4695 & 1.487 & 630 & 0.158 \\
\hline Ireland & 2.178 & 7474 & 2.020 & 344 & 0.158 & 1.998 & 5135 & 1.948 & 453 & 0.050 \\
\hline Italy & 1.984 & 15950 & 1.753 & 1251 & 0.230 & 1.909 & 10103 & 1.701 & 992 & 0.207 \\
\hline Netherlands & 2.194 & 13718 & 1.768 & 335 & 0.427 & 2.069 & 9070 & 1.739 & 448 & 0.330 \\
\hline Portugal & 1.433 & 12743 & 1.302 & 1448 & 0.130 & 1.353 & 9188 & 1.147 & 1583 & 0.206 \\
\hline Spain & 2.091 & 12378 & 1.636 & 5504 & 0.455 & 1.976 & 6437 & 1.577 & 3178 & 0.399 \\
\hline UK & 2.117 & 12324 & 1.980 & 435 & 0.138 & 1.940 & 11834 & 1.940 & 463 & -0.001 \\
\hline Total & 2.024 & 139423 & 1.699 & 14163 & 0.325 & 1.883 & 101193 & 1.638 & 12780 & 0.245 \\
\hline
\end{tabular}

Source: ECHP, 1995-2001. Sample weights are adjusted to that each country receives the same total weight.

Hourly earnings are in 2001 US purchasing power corrected dollars. 
Table 3: Selected Log Hourly Earnings Individual Fixed Effects Regression Results, Men

\begin{tabular}{|c|c|c|c|c|c|c|}
\hline & (1) & (2) & (3) & (4) & (5) & (6) \\
\hline \multirow[t]{2}{*}{ age } & $0.0803^{* *}$ & $0.0777^{* *}$ & $0.0765^{* *}$ & $0.0786 * *$ & $0.0760 * *$ & $0.0749 * *$ \\
\hline & $(0.0078)$ & $(0.0079)$ & $(0.0075)$ & $(0.0079)$ & $(0.0081)$ & $(0.0077)$ \\
\hline \multirow[t]{2}{*}{ agesq (/100) } & $-0.0626 * *$ & $-0.0575^{* *}$ & $-0.0564 * *$ & $-0.0607 * *$ & $-0.0555^{* *}$ & $-0.0544^{* *}$ \\
\hline & $(0.0069)$ & $(0.0067)$ & $(0.0063)$ & (0.0069) & $(0.0068)$ & $(0.0064)$ \\
\hline \multirow[t]{2}{*}{ edlow } & $-0.0377 * *$ & $-0.0356^{* *}$ & $-0.0346 * *$ & $-0.0393 * *$ & $-0.0372 * *$ & $-0.0362 * *$ \\
\hline & $(0.0086)$ & $(0.0080)$ & $(0.0081)$ & $(0.0077)$ & $(0.0071)$ & $(0.0073)$ \\
\hline \multirow[t]{2}{*}{ edmid } & $-0.0330 * *$ & $-0.0315^{* *}$ & $-0.0299 * *$ & $-0.0336 * *$ & $-0.0320 * *$ & $-0.0306^{* *}$ \\
\hline & $(0.0084)$ & $(0.0081)$ & $(0.0078)$ & $(0.0077)$ & $(0.0073)$ & $(0.0071)$ \\
\hline \multirow[t]{2}{*}{ temp } & $-0.0322 * *$ & $-0.0271 * *$ & $-0.0286 * *$ & $-0.3173 * *$ & $-0.3174^{* *}$ & $-0.3163^{* *}$ \\
\hline & $(0.0082)$ & $(0.0075)$ & $(0.0072)$ & (0.0968) & $(0.0976)$ & (0.0931) \\
\hline \multirow[t]{2}{*}{ unemrate } & -0.0017 & -0.0017 & -0.0016 & -0.0017 & -0.0017 & -0.0016 \\
\hline & (0.0019) & (0.0019) & (0.0019) & (0.0019) & (0.0019) & (0.0019) \\
\hline \multirow[t]{2}{*}{ tenure (years) } & & $0.0058^{* *}$ & $0.0059 * *$ & & $0.0057^{* *}$ & $0.0058^{* *}$ \\
\hline & & $(0.0011)$ & $(0.0010)$ & & $(0.0011)$ & $(0.0011)$ \\
\hline \multirow[t]{2}{*}{ tenuresq } & & $-0.0004^{* *}$ & $-0.0004 * *$ & & $-0.0004^{* *}$ & $-0.0004^{* *}$ \\
\hline & & $(0.0001)$ & $(0.0001)$ & & $(0.0001)$ & $(0.0001)$ \\
\hline \multirow[t]{2}{*}{ temp*age } & & & & $0.0155^{* *}$ & $0.0156^{* *}$ & $0.0154 * *$ \\
\hline & & & & (0.0048) & (0.0049) & $(0.0047)$ \\
\hline \multirow[t]{2}{*}{ temp*agesq $(/ 100)$} & & & & $-0.0200 * *$ & $-0.0204^{* *}$ & $-0.0200 * *$ \\
\hline & & & & $(0.0062)$ & $(0.0063)$ & $(0.0060)$ \\
\hline \multirow[t]{2}{*}{ temp*immig } & & & & $-0.0571+$ & $-0.0569+$ & $-0.0590+$ \\
\hline & & & & $(0.0267)$ & $(0.0266)$ & $(0.0276)$ \\
\hline \multirow[t]{2}{*}{ temp*edlow } & & & & $0.0279+$ & $0.0292+$ & $0.0289+$ \\
\hline & & & & (0.0149) & $(0.0151)$ & $(0.0153)$ \\
\hline \multirow[t]{2}{*}{ temp*edmid } & & & & 0.0149 & 0.0156 & 0.0167 \\
\hline & & & & $(0.0215)$ & $(0.0217)$ & $(0.0214)$ \\
\hline \multirow[t]{2}{*}{ temp*tenure } & & & & & 0.0023 & 0.0024 \\
\hline & & & & & $(0.0043)$ & $(0.0042)$ \\
\hline \multirow[t]{2}{*}{ temp*tenuresq } & & & & & -0.0001 & -0.0001 \\
\hline & & & & & $(0.0003)$ & $(0.0003)$ \\
\hline year dummies? & yes & yes & yes & yes & yes & yes \\
\hline occupation dummies? & no & no & yes & no & no & yes \\
\hline industry dummies? & no & no & yes & no & no & yes \\
\hline Sample size & 153586 & 153586 & 153586 & 153586 & 153586 & 153586 \\
\hline r squared & 0.131 & 0.132 & 0.136 & 0.132 & 0.133 & 0.136 \\
\hline
\end{tabular}

$+p<0.10, * p<0.05, * * p<0.01$

Standard errors clustered at the country level. Sample includes Austria, Belgium, Denmark, Finland, France, Germany, Greece, Ireland, Italy, Netherlands, Portugal, Spain, and the UK. Immig is defined as being either foreign born or a noncitizen. 
Table 4: Selected Log Hourly Earnings Individual Fixed Effects Regression Results, Wome

\begin{tabular}{|c|c|c|c|c|c|c|}
\hline & (1) & (2) & (3) & (4) & (5) & (6) \\
\hline \multirow[t]{2}{*}{ age } & $0.0738^{* *}$ & $0.0714^{* *}$ & $0.0699 * *$ & $0.0726^{* *}$ & $0.0703^{* *}$ & $0.0688^{* *}$ \\
\hline & $(0.0063)$ & $(0.0065)$ & $(0.0062)$ & $(0.0063)$ & $(0.0065)$ & $(0.0062)$ \\
\hline \multirow[t]{2}{*}{ agesq (/100) } & $-0.0530 * *$ & $-0.0487^{* *}$ & $-0.0474 * *$ & $-0.0515^{* *}$ & $-0.0476 * *$ & $-0.0462^{* *}$ \\
\hline & $(0.0057)$ & $(0.0061)$ & $(0.0058)$ & $(0.0056)$ & $(0.0060)$ & $(0.0057)$ \\
\hline \multirow[t]{2}{*}{ edlow } & $-0.0380 * *$ & $-0.0356^{* *}$ & $-0.0326 * *$ & $-0.0373 * *$ & $-0.0347^{* *}$ & $-0.0318^{* *}$ \\
\hline & $(0.0090)$ & (0.0089) & $(0.0087)$ & $(0.0089)$ & $(0.0088)$ & $(0.0087)$ \\
\hline \multirow[t]{2}{*}{ edmid } & $-0.0327^{* *}$ & $-0.0315^{* *}$ & $-0.0284^{*}$ & $-0.0316^{* *}$ & $-0.0303^{* *}$ & $-0.0272 *$ \\
\hline & $(0.0091)$ & (0.0093) & $(0.0095)$ & $(0.0092)$ & $(0.0093)$ & $(0.0096)$ \\
\hline \multirow[t]{2}{*}{ temp } & $-0.0149+$ & -0.0108 & -0.0122 & $-0.1805^{*}$ & $-0.1707^{*}$ & $-0.1757^{*}$ \\
\hline & $(0.0074)$ & $(0.0073)$ & $(0.0072)$ & $(0.0646)$ & $(0.0624)$ & $(0.0612)$ \\
\hline \multirow[t]{2}{*}{ unemrate } & -0.0021 & -0.0022 & -0.0021 & -0.0021 & -0.0022 & -0.0021 \\
\hline & $(0.0021)$ & $(0.0021)$ & $(0.0021)$ & $(0.0021)$ & $(0.0021)$ & $(0.0021)$ \\
\hline \multirow[t]{2}{*}{ tenure (years) } & & $0.0047^{*}$ & $0.0049 *$ & & $0.0038+$ & $0.0040+$ \\
\hline & & $(0.0021)$ & $(0.0021)$ & & $(0.0020)$ & $(0.0020)$ \\
\hline \multirow[t]{2}{*}{ tenuresq } & & $-0.0003+$ & $-0.0003+$ & & -0.0002 & $-0.0002+$ \\
\hline & & $(0.0001)$ & $(0.0001)$ & & $(0.0001)$ & $(0.0001)$ \\
\hline \multirow[t]{2}{*}{ temp*age } & & & & $0.0092^{*}$ & $0.0081^{*}$ & $0.0082 *$ \\
\hline & & & & $(0.0036)$ & $(0.0035)$ & $(0.0035)$ \\
\hline \multirow[t]{2}{*}{ temp*agesq $(/ 100)$} & & & & $-0.0116^{*}$ & $-0.0103+$ & $-0.0103+$ \\
\hline & & & & $(0.0050)$ & $(0.0049)$ & (0.0049) \\
\hline \multirow[t]{2}{*}{ temp*immig } & & & & -0.0310 & -0.0346 & -0.0365 \\
\hline & & & & $(0.0216)$ & $(0.0214)$ & $(0.0206)$ \\
\hline \multirow[t]{2}{*}{ temp*edlow } & & & & 0.0029 & 0.0048 & 0.0059 \\
\hline & & & & $(0.0152)$ & $(0.0154)$ & $(0.0149)$ \\
\hline \multirow[t]{2}{*}{ temp*edmid } & & & & -0.0037 & -0.0032 & -0.0029 \\
\hline & & & & $(0.0144)$ & $(0.0141)$ & $(0.0137)$ \\
\hline \multirow[t]{2}{*}{ temp*tenure } & & & & & $0.0135^{* *}$ & $0.0133 * *$ \\
\hline & & & & & $(0.0040)$ & $(0.0040)$ \\
\hline \multirow[t]{2}{*}{ temp*tenuresq } & & & & & $-0.0009 * *$ & $-0.0009 * *$ \\
\hline & & & & & $(0.0003)$ & $(0.0003)$ \\
\hline year dummies? & yes & yes & yes & yes & yes & yes \\
\hline occupation dummies? & no & no & yes & no & no & yes \\
\hline industry dummies? & no & no & yes & no & no & yes \\
\hline Sample size & 113973 & 113973 & 113973 & 113973 & 113973 & 113973 \\
\hline r squared & 0.143 & 0.144 & 0.148 & 0.143 & 0.144 & 0.149 \\
\hline
\end{tabular}

$+p<0.10, * p<0.05, * * p<0.01$

Standard errors clustered at the country level. Sample includes Austria, Belgium, Denmark, Finland, France, Germany, Greece, Ireland, Italy, Netherlands, Portugal, Spain, and the UK. Immig is defined as being either foreign born or a noncitizen. 
Table 5: Selected Log Hourly Earnings Individual Fixed Effects Regression Results, Foreign Born vs. Natives, Men

\begin{tabular}{|c|c|c|c|c|c|}
\hline & (1) & (2) & (3) & (4) & (5) \\
\hline \multirow[t]{2}{*}{ temp } & $-0.3882^{*}$ & $-0.3937^{*}$ & $-0.3992 *$ & $-0.3967^{*}$ & $-0.3946^{*}$ \\
\hline & $(0.1252)$ & $(0.1231)$ & $(0.1263)$ & $(0.1245)$ & (0.1155) \\
\hline \multirow[t]{2}{*}{ temp*age } & $0.0194^{*}$ & $0.0198 *$ & $0.0206^{*}$ & $0.0205^{*}$ & $0.0202 * *$ \\
\hline & $(0.0052)$ & $(0.0051)$ & $(0.0054)$ & $(0.0053)$ & $(0.0049)$ \\
\hline \multirow[t]{2}{*}{ temp*agesq } & $-0.0255^{* *}$ & $-0.0260 * *$ & $-0.0271 * *$ & $-0.0270 * *$ & $-0.0266 * *$ \\
\hline & $(0.0060)$ & $(0.0057)$ & $(0.0059)$ & $(0.0056)$ & $(0.0051)$ \\
\hline \multirow[t]{2}{*}{ temp*foreignborn } & -0.1089 & $-0.1700+$ & $-0.1682+$ & -0.3343 & -0.3308 \\
\hline & $(0.0600)$ & $(0.0812)$ & $(0.0810)$ & $(0.2302)$ & $(0.2239)$ \\
\hline \multirow[t]{2}{*}{ temp*edlow } & $0.0388+$ & $0.0388+$ & $0.0407+$ & $0.0405+$ & $0.0405+$ \\
\hline & $(0.0170)$ & $(0.0168)$ & (0.0169) & $(0.0170)$ & $(0.0167)$ \\
\hline \multirow[t]{2}{*}{ temp*edmid } & 0.0203 & 0.0191 & 0.0202 & 0.0202 & 0.0200 \\
\hline & $(0.0290)$ & $(0.0297)$ & (0.0304) & $(0.0300)$ & $(0.0274)$ \\
\hline \multirow[t]{2}{*}{ temp*foreignborn in the EU } & & $0.1478+$ & $0.1463+$ & $0.1338+$ & $0.1370+$ \\
\hline & & $(0.0667)$ & $(0.0686)$ & $(0.0610)$ & $(0.0646)$ \\
\hline \multirow[t]{2}{*}{ temp*tenure } & & & -0.0024 & -0.0025 & -0.0023 \\
\hline & & & $(0.0075)$ & $(0.0075)$ & $(0.0073)$ \\
\hline \multirow[t]{2}{*}{ temp*tenuresq } & & & 0.0001 & 0.0001 & 0.0001 \\
\hline & & & $(0.0005)$ & $(0.0005)$ & $(0.0005)$ \\
\hline \multirow[t]{2}{*}{ tenure } & & & $0.0070 *$ & $0.0071^{*}$ & $0.0073 *$ \\
\hline & & & $(0.0020)$ & $(0.0021)$ & $(0.0018)$ \\
\hline \multirow[t]{2}{*}{ tenuresq } & & & $-0.0004^{*}$ & $-0.0004^{*}$ & $-0.0004^{*}$ \\
\hline & & & $(0.0001)$ & $(0.0001)$ & $(0.0001)$ \\
\hline \multirow[t]{2}{*}{ years since migration (ysm) } & & & & -0.0065 & -0.0060 \\
\hline & & & & $(0.0069)$ & $(0.0077)$ \\
\hline \multirow[t]{2}{*}{ ysm squared } & & & & 0.0001 & 0.0001 \\
\hline & & & & $(0.0001)$ & $(0.0001)$ \\
\hline \multirow[t]{2}{*}{ temp*ysm } & & & & 0.0122 & 0.0114 \\
\hline & & & & $(0.0132)$ & (0.0129) \\
\hline \multirow[t]{2}{*}{ temp*ysm squared } & & & & -0.0002 & -0.0002 \\
\hline & & & & $(0.0002)$ & $(0.0002)$ \\
\hline \multicolumn{6}{|c|}{ Test H0: temp*foreignborn+tempforeignborn } \\
\hline in the $E U=0$ & & 0.4137 & 0.3963 & .4125 & .4219 \\
\hline year dummies? & yes & yes & yes & yes & yes \\
\hline industry and occupation dummies? & no & no & no & no & yes \\
\hline Sample size & 66024 & 66006 & 66006 & 66006 & 66006 \\
\hline r squared & 0.157 & 0.157 & 0.158 & 0.158 & 0.163 \\
\hline
\end{tabular}

$+p<0.10, * p<0.05, * * p<0.01$

Countries include Belgium, Denmark, France, Ireland, Portugal, and Spain.

Controls include age, age squared, edlow, edmid, and unemrate. Standard errors are clustered at the country level. 
Table 6: Selected Log Hourly Earnings Individual Fixed Effects Regression Results, Foreign Born vs. Natives, Women

\begin{tabular}{|c|c|c|c|c|c|}
\hline & (1) & (2) & (3) & (4) & (5) \\
\hline \multirow[t]{2}{*}{ temp } & $-0.2212^{* *}$ & $-0.2212^{* *}$ & $-0.2097^{* *}$ & $-0.2077^{* *}$ & $-0.2189 * *$ \\
\hline & $(0.0316)$ & $(0.0314)$ & $(0.0280)$ & $(0.0280)$ & (0.0299) \\
\hline \multirow[t]{2}{*}{ temp*age } & $0.0113^{* *}$ & $0.0113^{* *}$ & $0.0099 * *$ & $0.0097 * *$ & $0.0102 * *$ \\
\hline & $(0.0021)$ & $(0.0021)$ & $(0.0016)$ & $(0.0018)$ & $(0.0020)$ \\
\hline \multirow[t]{2}{*}{ temp*agesq } & $-0.0141 * *$ & $-0.0141 * *$ & $-0.0124 * *$ & $-0.0120 *$ & $-0.0124 *$ \\
\hline & $(0.0035)$ & $(0.0034)$ & $(0.0031)$ & $(0.0033)$ & $(0.0035)$ \\
\hline \multirow[t]{2}{*}{ temp*foreignborn } & -0.0215 & -0.0234 & -0.0298 & 0.2248 & 0.2145 \\
\hline & (0.0324) & $(0.0541)$ & $(0.0547)$ & (0.1281) & $(0.1286)$ \\
\hline \multirow[t]{2}{*}{ temp*edlow } & 0.0128 & 0.0127 & 0.0162 & 0.0161 & 0.0174 \\
\hline & $(0.0214)$ & $(0.0215)$ & $(0.0206)$ & $(0.0201)$ & (0.0193) \\
\hline \multirow[t]{2}{*}{ temp*edmid } & 0.0024 & 0.0024 & 0.0053 & 0.0052 & 0.0049 \\
\hline & $(0.0224)$ & $(0.0223)$ & $(0.0216)$ & $(0.0214)$ & $(0.0215)$ \\
\hline \multirow[t]{2}{*}{ temp*foreignborn in the EU } & & 0.0045 & 0.0091 & 0.0006 & 0.0002 \\
\hline & & $(0.0763)$ & $(0.0788)$ & $(0.0744)$ & $(0.0697)$ \\
\hline \multirow[t]{2}{*}{ temp*tenure } & & & $0.0177^{*}$ & $0.0178 *$ & $0.0171 *$ \\
\hline & & & $(0.0044)$ & $(0.0045)$ & $(0.0048)$ \\
\hline \multirow[t]{2}{*}{ temp*tenuresq } & & & $-0.0013^{*}$ & $-0.0013^{*}$ & $-0.0013^{*}$ \\
\hline & & & $(0.0004)$ & $(0.0004)$ & $(0.0004)$ \\
\hline \multirow[t]{2}{*}{ tenure } & & & $0.0083^{*}$ & $0.0084^{*}$ & $0.0088^{*}$ \\
\hline & & & $(0.0032)$ & $(0.0032)$ & $(0.0030)$ \\
\hline \multirow[t]{2}{*}{ tenuresq } & & & $-0.0005+$ & $-0.0005+$ & $-0.0005^{*}$ \\
\hline & & & $(0.0002)$ & $(0.0002)$ & $(0.0002)$ \\
\hline \multirow[t]{2}{*}{ years since migration (ysm) } & & & & $0.0109+$ & 0.0103+ \\
\hline & & & & $(0.0045)$ & $(0.0045)$ \\
\hline \multirow[t]{2}{*}{ ysm squared } & & & & $-0.0002^{*}$ & $-0.0002 *$ \\
\hline & & & & $(0.0001)$ & $(0.0001)$ \\
\hline \multirow[t]{2}{*}{ temp*ysm } & & & & $-0.0186+$ & $-0.0175+$ \\
\hline & & & & $(0.0079)$ & $(0.0082)$ \\
\hline \multirow[t]{2}{*}{ temp*ysm squared } & & & & 0.0003 & 0.0003 \\
\hline & & & & $(0.0002)$ & $(0.0002)$ \\
\hline \multicolumn{6}{|c|}{ Test HO: temp*foreignborn+tempforeignborn } \\
\hline in the $E U=0$ & & 0.6845 & 0.6535 & 0.0162 & 0.0292 \\
\hline year dummies? & yes & yes & yes & yes & yes \\
\hline industry and occupation dummies? & no & no & no & no & yes \\
\hline Sample size & 48619 & 48615 & 48615 & 48615 & 48615 \\
\hline r squared & 0.176 & 0.176 & 0.179 & 0.179 & 0.187 \\
\hline
\end{tabular}

$+p<0.10{ }^{*} p<0.05, * * p<0.01$. Countries include Belgium, Denmark, France, Ireland, Portugal, and Spain. Controls include age, age squared, edlow, edmid, and unemrate. Standard errors are clustered at the country level. 
Table A1: Selected Log Hourly Earnings Individual Fixed Effects Regression Results, by Country, Men

\begin{tabular}{|c|c|c|c|c|c|c|c|c|c|c|}
\hline \multirow[b]{2}{*}{ temp } & \multicolumn{2}{|c|}{ Austria } & \multicolumn{2}{|c|}{ Belgium } & \multicolumn{2}{|c|}{ Denmark } & \multicolumn{2}{|c|}{ Finland } & \multicolumn{2}{|c|}{ France } \\
\hline & $\begin{array}{c}-0.0137 \\
(0.0177)\end{array}$ & $\begin{array}{c}-0.2613 \\
(0.2502)\end{array}$ & $\begin{array}{c}-0.0282 \\
(0.0294)\end{array}$ & $\begin{array}{c}-0.6336 \\
(0.4184)\end{array}$ & $\begin{array}{c}-0.0147 \\
(0.0312)\end{array}$ & $\begin{array}{c}-0.5089 \\
(0.3690)\end{array}$ & $\begin{array}{r}-0.0260 \\
(0.0209)\end{array}$ & $\begin{array}{r}-0.2830 \\
(0.2741)\end{array}$ & $\begin{array}{c}0.0130 \\
(0.0216)\end{array}$ & $\begin{array}{c}-0.6992^{*} \\
(0.2930)\end{array}$ \\
\hline tenure & $\begin{array}{c}0.0083^{*} \\
(0.0033)\end{array}$ & $\begin{array}{c}0.0081^{*} \\
(0.0033)\end{array}$ & $\begin{array}{c}0.0051 \\
(0.0044)\end{array}$ & $\begin{array}{c}0.0046 \\
(0.0043)\end{array}$ & $\begin{array}{c}0.0051 \\
(0.0031)\end{array}$ & $\begin{array}{c}0.0070^{*} \\
(0.0030)\end{array}$ & $\begin{array}{c}0.0047 \\
(0.0042)\end{array}$ & $\begin{array}{c}0.0018 \\
(0.0042)\end{array}$ & $\begin{array}{c}0.0119 * * \\
(0.0029)\end{array}$ & $\begin{array}{c}0.0154^{* *} \\
(0.0029)\end{array}$ \\
\hline tenuresq & $\begin{array}{c}-0.0003+ \\
(0.0002)\end{array}$ & $\begin{array}{r}-0.0003 \\
(0.0002)\end{array}$ & $\begin{array}{c}-0.0001 \\
(0.0002)\end{array}$ & $\begin{array}{c}-0.0001 \\
(0.0003)\end{array}$ & $\begin{array}{c}-0.0003+ \\
(0.0002)\end{array}$ & $\begin{array}{c}-0.0004^{*} \\
(0.0002)\end{array}$ & $\begin{array}{c}-0.0006^{*} \\
(0.0003)\end{array}$ & $\begin{array}{c}-0.0004 \\
(0.0003)\end{array}$ & $\begin{array}{r}-0.0004^{*} \\
(0.0002)\end{array}$ & $\begin{array}{c}-0.0005^{* *} \\
(0.0002)\end{array}$ \\
\hline temp*age & & $\begin{array}{c}0.0167 \\
(0.0137)\end{array}$ & & $\begin{array}{c}0.0306 \\
(0.0214)\end{array}$ & & $\begin{array}{c}0.0311+ \\
(0.0186)\end{array}$ & & $\begin{array}{c}0.0114 \\
(0.0152)\end{array}$ & & $\begin{array}{l}0.0410^{*} \\
(0.0175)\end{array}$ \\
\hline temp*agesq $(/ 100)$ & & $\begin{array}{l}-0.0219 \\
(0.0177)\end{array}$ & & $\begin{array}{r}-0.0378 \\
(0.0280)\end{array}$ & & $\begin{array}{c}-0.0373+ \\
(0.0226)\end{array}$ & & $\begin{array}{l}-0.0117 \\
(0.0204)\end{array}$ & & $\begin{array}{l}-0.0520 * \\
(0.0246)\end{array}$ \\
\hline temp*immig & & $\begin{array}{c}-0.0786+ \\
(0.0476)\end{array}$ & & $\begin{array}{c}-0.0181 \\
(0.0466)\end{array}$ & & $\begin{array}{c}-0.1822 \\
(0.1782)\end{array}$ & & $\begin{array}{c}-0.1614+ \\
(0.0926)\end{array}$ & & $\begin{array}{r}-0.0339 \\
(0.0592)\end{array}$ \\
\hline temp*edlow & & $\begin{array}{r}-0.0787 \\
(0.0646)\end{array}$ & & $\begin{array}{c}0.0674 \\
(0.0729)\end{array}$ & & $\begin{array}{c}0.0136 \\
(0.0854)\end{array}$ & & $\begin{array}{c}0.0344 \\
(0.0701)\end{array}$ & & $\begin{array}{c}0.0041 \\
(0.0494)\end{array}$ \\
\hline temp*edmid & & $\begin{array}{r}-0.0173 \\
(0.0610)\end{array}$ & & $\begin{array}{c}0.0756 \\
(0.0718)\end{array}$ & & $\begin{array}{r}-0.0728 \\
(0.0600)\end{array}$ & & $\begin{array}{c}-0.0384 \\
(0.0343)\end{array}$ & & $\begin{array}{r}-0.0006 \\
(0.0476)\end{array}$ \\
\hline temp*tenure & & $\begin{array}{r}-0.0016 \\
(0.0107)\end{array}$ & & $\begin{array}{c}-0.0071 \\
(0.0182)\end{array}$ & & $\begin{array}{c}-0.0644^{* *} \\
(0.0196)\end{array}$ & & $\begin{array}{c}0.0384^{*} \\
(0.0150)\end{array}$ & & $\begin{array}{c}-0.0132 \\
(0.0148)\end{array}$ \\
\hline temp*tenuresq & & $\begin{array}{c}0.0002 \\
(0.0007)\end{array}$ & & $\begin{array}{c}0.0003 \\
(0.0013)\end{array}$ & & $\begin{array}{c}0.0042^{*} \\
(0.0018)\end{array}$ & & $\begin{array}{c}-0.0031^{*} \\
(0.0014)\end{array}$ & & $\begin{array}{l}-0.0009 \\
(0.0020)\end{array}$ \\
\hline year dummies? & yes & yes & yes & yes & yes & yes & yes & yes & yes & yes \\
\hline Industry, occupation dummies? & no & yes & no & yes & no & yes & no & yes & no & yes \\
\hline Sample Size & 10251 & 10251 & 5120 & 5120 & 6032 & 6032 & 6502 & 6502 & 14981 & 14981 \\
\hline r squared & 0.129 & 0.143 & 0.092 & 0.123 & 0.183 & 0.217 & 0.144 & 0.163 & 0.170 & 0.181 \\
\hline
\end{tabular}


Table A1: Selected Log Hourly Earnings Individual Fixed Effects Regression Results, by Country, Men (ctd)

\begin{tabular}{|c|c|c|c|c|c|c|c|c|c|c|}
\hline \multirow[b]{2}{*}{ temp } & \multicolumn{2}{|c|}{ Germany } & \multicolumn{2}{|c|}{ Greece } & \multicolumn{2}{|c|}{ Ireland } & \multicolumn{2}{|c|}{ Italy } & \multicolumn{2}{|c|}{ Netherlands } \\
\hline & $\begin{array}{c}-0.0331+ \\
(0.0177)\end{array}$ & $\begin{array}{c}-0.3360 \\
(0.2148)\end{array}$ & $\begin{array}{c}-0.0383+ \\
(0.0223)\end{array}$ & $\begin{array}{c}0.3449 \\
(0.2271)\end{array}$ & $\begin{array}{c}0.0490 \\
(0.0318)\end{array}$ & $\begin{array}{c}-0.2468 \\
(0.2506)\end{array}$ & $\begin{array}{c}-0.0058 \\
(0.0117)\end{array}$ & $\begin{array}{r}-0.1030 \\
(0.1332)\end{array}$ & $\begin{array}{c}-0.0433+ \\
(0.0245)\end{array}$ & $\begin{array}{c}0.1882 \\
(0.3897)\end{array}$ \\
\hline tenure & $\begin{array}{c}0.0078^{* *} \\
(0.0028)\end{array}$ & $\begin{array}{c}0.0077^{* *} \\
(0.0027)\end{array}$ & $\begin{array}{l}0.0142 * * \\
(0.0044)\end{array}$ & $\begin{array}{c}0.0143^{* *} \\
(0.0046)\end{array}$ & $\begin{array}{c}0.0019 \\
(0.0058)\end{array}$ & $\begin{array}{c}0.0033 \\
(0.0059)\end{array}$ & $\begin{array}{c}0.0047+ \\
(0.0025)\end{array}$ & $\begin{array}{c}0.0048+ \\
(0.0025)\end{array}$ & $\begin{array}{c}0.0035 \\
(0.0030)\end{array}$ & $\begin{array}{c}0.0028 \\
(0.0030)\end{array}$ \\
\hline tenuresq & $\begin{array}{l}-0.0003 \\
(0.0002)\end{array}$ & $\begin{array}{c}-0.0003+ \\
(0.0002)\end{array}$ & $\begin{array}{c}-0.0008 * * \\
(0.0003)\end{array}$ & $\begin{array}{c}-0.0008 * * \\
(0.0003)\end{array}$ & $\begin{array}{c}-0.0006+ \\
(0.0003)\end{array}$ & $\begin{array}{c}-0.0007+ \\
(0.0003)\end{array}$ & $\begin{array}{c}-0.0004 * * \\
(0.0001)\end{array}$ & $\begin{array}{c}-0.0004^{* *} \\
(0.0001)\end{array}$ & $\begin{array}{c}-0.0004+ \\
(0.0002)\end{array}$ & $\begin{array}{l}-0.0003+ \\
(0.0002)\end{array}$ \\
\hline temp*age & & $\begin{array}{c}0.0143 \\
(0.0121)\end{array}$ & & $\begin{array}{c}-0.0230+ \\
(0.0121)\end{array}$ & & $\begin{array}{c}0.0207 \\
(0.0132)\end{array}$ & & $\begin{array}{c}0.0054 \\
(0.0065)\end{array}$ & & $\begin{array}{l}-0.0138 \\
(0.0213)\end{array}$ \\
\hline temp*agesq $(/ 100)$ & & $\begin{array}{c}-0.0207 \\
(0.0158)\end{array}$ & & $\begin{array}{c}0.0312^{*} \\
(0.0156)\end{array}$ & & $\begin{array}{c}-0.0313+ \\
(0.0165)\end{array}$ & & $\begin{array}{c}-0.0072 \\
(0.0082)\end{array}$ & & $\begin{array}{c}0.0154 \\
(0.0273)\end{array}$ \\
\hline temp*immig & & $\begin{array}{c}-0.0967+ \\
(0.0543)\end{array}$ & & $\begin{array}{c}0.0931 \\
(0.1166)\end{array}$ & & $\begin{array}{r}-0.0788 \\
(0.1585)\end{array}$ & & $\begin{array}{c}-0.0807+ \\
(0.0489)\end{array}$ & & $\begin{array}{c}0.0049 \\
(0.0825)\end{array}$ \\
\hline temp*edlow & & $\begin{array}{c}0.1123^{*} \\
(0.0508)\end{array}$ & & $\begin{array}{c}0.0191 \\
(0.0609)\end{array}$ & & $\begin{array}{c}0.0653 \\
(0.0834)\end{array}$ & & $\begin{array}{c}0.0256 \\
(0.0443)\end{array}$ & & $\begin{array}{c}0.0160 \\
(0.0671)\end{array}$ \\
\hline temp*edmid & & $\begin{array}{c}0.1037^{*} \\
(0.0437)\end{array}$ & & $\begin{array}{r}-0.0226 \\
(0.0596)\end{array}$ & & $\begin{array}{l}-0.0477 \\
(0.0757)\end{array}$ & & $\begin{array}{l}-0.0136 \\
(0.0434)\end{array}$ & & $\begin{array}{c}0.0156 \\
(0.0605)\end{array}$ \\
\hline temp*tenure & & $\begin{array}{c}0.0128 \\
(0.0122)\end{array}$ & & $\begin{array}{c}0.0042 \\
(0.0152)\end{array}$ & & $\begin{array}{c}-0.0132 \\
(0.0228)\end{array}$ & & $\begin{array}{c}-0.0021 \\
(0.0072)\end{array}$ & & $\begin{array}{c}0.0350 \\
(0.0280)\end{array}$ \\
\hline temp*tenuresq & & $\begin{array}{l}-0.0006 \\
(0.0010)\end{array}$ & & $\begin{array}{c}-0.0002 \\
(0.0009)\end{array}$ & & $\begin{array}{c}0.0018 \\
(0.0017)\end{array}$ & & $\begin{array}{c}0.0002 \\
(0.0005)\end{array}$ & & $\begin{array}{l}-0.0025 \\
(0.0019)\end{array}$ \\
\hline year dummies? & yes & yes & yes & yes & yes & yes & yes & yes & yes & yes \\
\hline Industry, occupation dummies? & no & yes & no & yes & no & yes & no & yes & no & yes \\
\hline Sample Size & 18207 & 18207 & 8589 & 8589 & 7818 & 7818 & 17201 & 17201 & 14053 & 14053 \\
\hline r squared & 0.079 & 0.098 & 0.191 & 0.208 & 0.152 & 0.167 & 0.116 & 0.122 & 0.097 & 0.103 \\
\hline
\end{tabular}


Table A1: Selected Log Hourly Earnings Individual Fixed Effects Regression Results, by Country, Men (ctd)

\begin{tabular}{|c|c|c|c|c|c|c|}
\hline \multirow[b]{2}{*}{ temp } & \multicolumn{2}{|c|}{ Portugal } & \multicolumn{2}{|c|}{ Spain } & \multicolumn{2}{|c|}{ UK } \\
\hline & -0.0242 & -0.1114 & $-0.0431^{* *}$ & $-0.5636 * *$ & -0.0323 & -0.4435 \\
\hline & $(0.0188)$ & $(0.1871)$ & $(0.0117)$ & $(0.1242)$ & $(0.0278)$ & (0.2729) \\
\hline \multirow[t]{2}{*}{ tenure } & 0.0024 & 0.0034 & $0.0127^{* *}$ & $0.0124^{* *}$ & 0.0014 & 0.0024 \\
\hline & $(0.0045)$ & $(0.0045)$ & $(0.0033)$ & $(0.0039)$ & $(0.0023)$ & $(0.0023)$ \\
\hline \multirow[t]{2}{*}{ tenuresq } & -0.0002 & -0.0003 & $-0.0009 * *$ & $-0.0009 * *$ & -0.0000 & -0.0001 \\
\hline & $(0.0002)$ & $(0.0003)$ & $(0.0002)$ & $(0.0002)$ & $(0.0002)$ & $(0.0002)$ \\
\hline \multirow[t]{2}{*}{ temp*age } & & 0.0065 & & $0.0259 * *$ & & $0.0305+$ \\
\hline & & $(0.0102)$ & & $(0.0066)$ & & $(0.0157)$ \\
\hline \multirow[t]{2}{*}{ temp*agesq $(/ 100)$} & & -0.0129 & & $-0.0331 * *$ & & $-0.0421^{*}$ \\
\hline & & $(0.0128)$ & & $(0.0084)$ & & $(0.0214)$ \\
\hline \multirow[t]{2}{*}{ temp*immig } & & $-0.1801+$ & & 0.0017 & & -0.0451 \\
\hline & & $(0.0924)$ & & $(0.0504)$ & & $(0.0765)$ \\
\hline \multirow[t]{2}{*}{ temp*edlow } & & 0.0380 & & $0.0752^{* *}$ & & $-0.1170 *$ \\
\hline & & $(0.0606)$ & & $(0.0263)$ & & $(0.0548)$ \\
\hline \multirow[t]{2}{*}{ temp*edmid } & & -0.0202 & & $0.0511+$ & & $-0.1475+$ \\
\hline & & $(0.0578)$ & & $(0.0296)$ & & $(0.0783)$ \\
\hline \multirow[t]{2}{*}{ temp*tenure } & & 0.0058 & & 0.0036 & & -0.0312 \\
\hline & & $(0.0117)$ & & $(0.0065)$ & & $(0.0222)$ \\
\hline \multirow[t]{2}{*}{ temp*tenuresq } & & 0.0001 & & -0.0004 & & $0.0034^{*}$ \\
\hline & & $(0.0010)$ & & $(0.0005)$ & & $(0.0017)$ \\
\hline year dummies? & yes & yes & yes & yes & yes & yes \\
\hline Industry, occupation dummies? & no & yes & no & yes & no & yes \\
\hline Sample Size & 14191 & 14191 & 17882 & 17882 & 12759 & 12759 \\
\hline r squared & 0.276 & 0.296 & 0.159 & 0.171 & 0.224 & 0.244 \\
\hline
\end{tabular}

$+p<0.10,{ }^{*} p<.05,{ }^{* *} P<.01$. Controls include age, age squared, edlow, edmid, and unemrate. Standard errors are clustered at the individual level. 
Table A2: Selected Log Hourly Earnings Individual Fixed Effects Regression Results, by Country, Women

\begin{tabular}{|c|c|c|c|c|c|c|c|c|c|c|}
\hline \multirow[b]{2}{*}{ temp } & \multicolumn{2}{|c|}{ Austria } & \multicolumn{2}{|c|}{ Belgium } & \multicolumn{2}{|c|}{ Denmark } & \multicolumn{2}{|c|}{ Finland } & \multicolumn{2}{|c|}{ France } \\
\hline & $\begin{array}{c}0.0088 \\
(0.0216)\end{array}$ & $\begin{array}{c}-0.5023 \\
(0.3111)\end{array}$ & $\begin{array}{l}0.0292+ \\
(0.0167)\end{array}$ & $\begin{array}{c}-0.0581 \\
(0.2478)\end{array}$ & $\begin{array}{l}-0.0483^{*} \\
(0.0212)\end{array}$ & $\begin{array}{c}-0.0268 \\
(0.2439)\end{array}$ & $\begin{array}{c}-0.0121 \\
(0.0192)\end{array}$ & $\begin{array}{c}0.2881 \\
(0.2416)\end{array}$ & $\begin{array}{c}-0.0161 \\
(0.0222)\end{array}$ & $\begin{array}{c}-0.1821 \\
(0.2601)\end{array}$ \\
\hline tenure & $\begin{array}{r}-0.0043 \\
(0.0044)\end{array}$ & $\begin{array}{c}-0.0062 \\
(0.0045)\end{array}$ & $\begin{array}{c}0.0070+ \\
(0.0042)\end{array}$ & $\begin{array}{c}0.0059 \\
(0.0044)\end{array}$ & $\begin{array}{r}-0.0000 \\
(0.0027)\end{array}$ & $\begin{array}{c}0.0014 \\
(0.0027)\end{array}$ & $\begin{array}{c}0.0027 \\
(0.0044)\end{array}$ & $\begin{array}{r}-0.0025 \\
(0.0045)\end{array}$ & $\begin{array}{c}0.0148 * * \\
(0.0038)\end{array}$ & $\begin{array}{c}0.0115^{* *} \\
(0.0040)\end{array}$ \\
\hline tenuresq & $\begin{array}{c}-0.0002 \\
(0.0003)\end{array}$ & $\begin{array}{c}-0.0001 \\
(0.0003)\end{array}$ & $\begin{array}{l}-0.0004 \\
(0.0002)\end{array}$ & $\begin{array}{r}-0.0003 \\
(0.0002)\end{array}$ & $\begin{array}{c}-0.0001 \\
(0.0001)\end{array}$ & $\begin{array}{c}-0.0001 \\
(0.0001)\end{array}$ & $\begin{array}{c}-0.0002 \\
(0.0003)\end{array}$ & $\begin{array}{c}0.0000 \\
(0.0003)\end{array}$ & $\begin{array}{c}-0.0008^{* *} \\
(0.0002)\end{array}$ & $\begin{array}{c}-0.0007^{* *} \\
(0.0002)\end{array}$ \\
\hline temp*age & & $\begin{array}{c}0.0356^{*} \\
(0.0179)\end{array}$ & & $\begin{array}{c}0.0052 \\
(0.0141)\end{array}$ & & $\begin{array}{l}-0.0011 \\
(0.0128)\end{array}$ & & $\begin{array}{l}-0.0193 \\
(0.0137)\end{array}$ & & $\begin{array}{c}0.0066 \\
(0.0149)\end{array}$ \\
\hline temp*agesq $(/ 100)$ & & $\begin{array}{c}-0.0508^{*} \\
(0.0245)\end{array}$ & & $\begin{array}{r}-0.0089 \\
(0.0190)\end{array}$ & & $\begin{array}{c}0.0037 \\
(0.0165)\end{array}$ & & $\begin{array}{c}0.0268 \\
(0.0188)\end{array}$ & & $\begin{array}{r}-0.0076 \\
(0.0203)\end{array}$ \\
\hline temp*immig & & $\begin{array}{r}-0.0386 \\
(0.0426)\end{array}$ & & $\begin{array}{l}-0.0169 \\
(0.0400)\end{array}$ & & $\begin{array}{c}0.0186 \\
(0.0516)\end{array}$ & & $\begin{array}{c}-0.1648+ \\
(0.0876)\end{array}$ & & $\begin{array}{r}-0.0199 \\
(0.0993)\end{array}$ \\
\hline temp*edlow & & $\begin{array}{c}-0.1098+ \\
(0.0577)\end{array}$ & & $\begin{array}{c}-0.0087 \\
(0.0570)\end{array}$ & & $\begin{array}{r}-0.0418 \\
(0.0473)\end{array}$ & & $\begin{array}{c}0.0128 \\
(0.0482)\end{array}$ & & $\begin{array}{r}-0.0415 \\
(0.0605)\end{array}$ \\
\hline temp*edmid & & $\begin{array}{c}-0.1199^{*} \\
(0.0476)\end{array}$ & & $\begin{array}{r}-0.0090 \\
(0.0368)\end{array}$ & & $\begin{array}{r}-0.0450 \\
(0.0451)\end{array}$ & & $\begin{array}{c}0.0064 \\
(0.0293)\end{array}$ & & $\begin{array}{r}-0.0139 \\
(0.0500)\end{array}$ \\
\hline temp*tenure & & $\begin{array}{c}0.0133 \\
(0.0136)\end{array}$ & & $\begin{array}{c}0.0042 \\
(0.0096)\end{array}$ & & $\begin{array}{r}-0.0113 \\
(0.0205)\end{array}$ & & $\begin{array}{c}0.0208^{*} \\
(0.0102)\end{array}$ & & $\begin{array}{c}0.0419 * * \\
(0.0151)\end{array}$ \\
\hline temp*tenuresq & & $\begin{array}{r}-0.0003 \\
(0.0009)\end{array}$ & & $\begin{array}{c}0.0001 \\
(0.0006)\end{array}$ & & $\begin{array}{c}0.0005 \\
(0.0017)\end{array}$ & & $\begin{array}{r}-0.0012 \\
(0.0007)\end{array}$ & & $\begin{array}{c}-0.0033^{*} \\
(0.0014)\end{array}$ \\
\hline year dummies? & yes & yes & yes & yes & yes & yes & yes & yes & yes & yes \\
\hline Industry, occupation dummies? & no & yes & no & yes & no & yes & no & yes & no & yes \\
\hline Sample Size & 7212 & 7212 & 4267 & 4267 & 5830 & 5830 & 6641 & 6641 & 12548 & 12548 \\
\hline rsquared & 0.116 & 0.138 & 0.107 & 0.123 & 0.269 & 0.293 & 0.105 & 0.132 & 0.151 & 0.160 \\
\hline
\end{tabular}


Table A2: Selected Log Hourly Earnings Individual Fixed Effects Regression Results, by Country, Women (ctd)

\begin{tabular}{|c|c|c|c|c|c|c|c|c|c|c|}
\hline \multirow[b]{2}{*}{ temp } & \multicolumn{2}{|c|}{ Germany } & \multicolumn{2}{|c|}{ Greece } & \multicolumn{2}{|c|}{ Ireland } & \multicolumn{2}{|c|}{ Italy } & \multicolumn{2}{|c|}{ Netherlands } \\
\hline & $-0.0370+$ & $-0.5414^{*}$ & -0.0044 & 0.1235 & 0.0269 & -0.4677 & -0.0099 & $-0.3133+$ & $-0.0618^{* *}$ & -0.2099 \\
\hline & (0.0191) & $(0.2524)$ & $(0.0236)$ & $(0.3657)$ & $(0.0278)$ & $(0.4020)$ & $(0.0154)$ & (0.1769) & $(0.0197)$ & (0.2198) \\
\hline \multirow[t]{2}{*}{ tenure } & $0.0066^{*}$ & $0.0070^{*}$ & 0.0002 & 0.0017 & $0.0131 *$ & $0.0145^{* *}$ & 0.0020 & 0.0029 & $0.0090^{*}$ & $0.0083^{*}$ \\
\hline & $(0.0032)$ & $(0.0032)$ & $(0.0055)$ & $(0.0056)$ & $(0.0052)$ & $(0.0047)$ & $(0.0033)$ & (0.0034) & $(0.0035)$ & $(0.0035)$ \\
\hline \multirow[t]{2}{*}{ tenuresq } & -0.0002 & -0.0003 & 0.0003 & 0.0002 & $-0.0010^{* *}$ & $-0.0011^{* *}$ & -0.0001 & -0.0002 & -0.0003 & -0.0003 \\
\hline & $(0.0002)$ & $(0.0002)$ & $(0.0003)$ & $(0.0003)$ & $(0.0003)$ & $(0.0003)$ & $(0.0002)$ & $(0.0002)$ & $(0.0002)$ & (0.0002) \\
\hline \multirow[t]{2}{*}{ temp*age } & & $0.0230+$ & & -0.0032 & & 0.0262 & & $0.0164+$ & & 0.0111 \\
\hline & & $(0.0120)$ & & $(0.0221)$ & & $(0.0252)$ & & $(0.0096)$ & & $(0.0120)$ \\
\hline \multirow[t]{2}{*}{ temp*agesq $(/ 100)$} & & $-0.0261+$ & & 0.0023 & & -0.0377 & & $-0.0237+$ & & -0.0168 \\
\hline & & $(0.0148)$ & & $(0.0325)$ & & $(0.0375)$ & & $(0.0136)$ & & (0.0151) \\
\hline \multirow[t]{2}{*}{ temp*immig } & & 0.0492 & & -0.0743 & & -0.0865 & & 0.0721 & & $-0.1454^{*}$ \\
\hline & & $(0.0435)$ & & $(0.0526)$ & & $(0.0662)$ & & $(0.0609)$ & & (0.0678) \\
\hline \multirow[t]{2}{*}{ temp*edlow } & & 0.0674 & & -0.0461 & & $0.1178+$ & & 0.0709 & & -0.0302 \\
\hline & & $(0.0631)$ & & $(0.0748)$ & & $(0.0708)$ & & $(0.0604)$ & & (0.0568) \\
\hline \multirow[t]{2}{*}{ temp*edmid } & & 0.0271 & & -0.0357 & & $0.1080^{*}$ & & 0.0469 & & -0.0537 \\
\hline & & $(0.0507)$ & & $(0.0464)$ & & $(0.0538)$ & & $(0.0632)$ & & (0.0578) \\
\hline \multirow[t]{2}{*}{ temp*tenure } & & 0.0031 & & -0.0107 & & 0.0056 & & -0.0066 & & 0.0310 \\
\hline & & $(0.0101)$ & & $(0.0155)$ & & $(0.0196)$ & & $(0.0078)$ & & $(0.0253)$ \\
\hline \multirow[t]{2}{*}{ temp*tenuresq } & & -0.0002 & & 0.0004 & & -0.0001 & & 0.0005 & & -0.0016 \\
\hline & & $(0.0005)$ & & $(0.0012)$ & & $(0.0013)$ & & $(0.0005)$ & & $(0.0021)$ \\
\hline year dummies? & yes & yes & yes & yes & yes & yes & yes & yes & yes & yes \\
\hline Industry, occupation dummies? & no & yes & no & yes & no & yes & no & yes & no & yes \\
\hline Sample Size & 13266 & 13266 & 5325 & 5325 & 5588 & 5588 & 11095 & 11095 & 9518 & 9518 \\
\hline rsquared & 0.068 & 0.087 & 0.231 & 0.247 & 0.249 & 0.275 & 0.100 & 0.104 & 0.168 & 0.178 \\
\hline
\end{tabular}


Table A2: Selected Log Hourly Earnings Individual Fixed Effects Regression Results, by Country, Women (ctd)

\begin{tabular}{|c|c|c|c|c|c|c|}
\hline \multirow[b]{2}{*}{ temp } & \multicolumn{2}{|c|}{ Portugal } & \multicolumn{2}{|c|}{ Spain } & \multicolumn{2}{|c|}{ UK } \\
\hline & 0.0032 & -0.2178 & -0.0117 & -0.1542 & 0.0003 & -0.1197 \\
\hline & $(0.0173)$ & $(0.1643)$ & $(0.0209)$ & $(0.1400)$ & $(0.0225)$ & (0.2479) \\
\hline \multirow[t]{2}{*}{ tenure } & 0.0015 & 0.0000 & 0.0164 & 0.0138 & -0.0001 & 0.0010 \\
\hline & $(0.0040)$ & $(0.0040)$ & $(0.0100)$ & $(0.0093)$ & $(0.0026)$ & $(0.0025)$ \\
\hline \multirow[t]{2}{*}{ tenuresq } & -0.0002 & -0.0001 & $-0.0013^{*}$ & $-0.0010^{*}$ & -0.0001 & -0.0001 \\
\hline & $(0.0003)$ & $(0.0003)$ & $(0.0006)$ & $(0.0005)$ & $(0.0002)$ & $(0.0002)$ \\
\hline \multirow[t]{2}{*}{ temp*age } & & 0.0146 & & 0.0043 & & 0.0084 \\
\hline & & $(0.0096)$ & & $(0.0078)$ & & $(0.0145)$ \\
\hline \multirow[t]{2}{*}{ temp*agesq $(/ 100)$} & & -0.0204 & & -0.0018 & & -0.0084 \\
\hline & & $(0.0141)$ & & $(0.0110)$ & & (0.0197) \\
\hline \multirow[t]{2}{*}{ temp*immig } & & -0.0703 & & 0.0736 & & -0.0814 \\
\hline & & $(0.0462)$ & & $(0.0604)$ & & (0.1053) \\
\hline \multirow[t]{2}{*}{ temp*edlow } & & -0.0493 & & 0.0237 & & $-0.0719+$ \\
\hline & & $(0.0405)$ & & $(0.0278)$ & & (0.0431) \\
\hline \multirow[t]{2}{*}{ temp*edmid } & & -0.0513 & & 0.0082 & & -0.0388 \\
\hline & & $(0.0465)$ & & $(0.0265)$ & & (0.0699) \\
\hline \multirow[t]{2}{*}{ temp*tenure } & & 0.0230 & & 0.0134 & & -0.0248 \\
\hline & & $(0.0141)$ & & $(0.0095)$ & & $(0.0206)$ \\
\hline \multirow[t]{2}{*}{ temp*tenuresq } & & -0.0016 & & $-0.0015^{*}$ & & 0.0011 \\
\hline & & $(0.0011)$ & & $(0.0006)$ & & $(0.0018)$ \\
\hline year dummies? & yes & yes & yes & yes & yes & yes \\
\hline Industry, occupation dummies? & no & yes & no & yes & no & yes \\
\hline Sample Size & 10771 & 10771 & 9615 & 9615 & 12297 & 12297 \\
\hline r squared & 0.292 & 0.315 & 0.164 & 0.198 & 0.181 & 0.195 \\
\hline
\end{tabular}

$+p<0.10,{ }^{*} p<.05,{ }^{*} P<.01$. Controls include age, age squared, edlow, edmid, and unemrate. Standard errors are clustered at the individual level. 